\title{
15. OCEAN CRUST GEOTHERMAL PROCESSES: A PERSPECTIVE FROM THE VANTAGE OF LEG 54 DRILLING
}

\author{
Roger Hekinian, Centre Océanologique de Bretagne, 29273 Brest, France \\ Bruce R. Rosendahl, Department of Geology, Duke University, Durham, North Carolina \\ and \\ James H. Natland, Deep Sea Drilling Project, Scripps Institution of Oceanography, La Jolla, California
}

\begin{abstract}
Two distinct sedimentary facies produced by sea-floor hydrothermal activity were cored during Deep Sea Drilling Project Leg 54. The first is equivalent to the typical basal iron- and manganese-rich, clayey mud recovered at many DSDP sites. It was sampled as a dispersed component throughout the cores taken in small sediment ponds in several sites within $120 \mathrm{~km}$ of the East Pacific Rise at $9^{\circ} \mathrm{N}$. We infer that this component was originally deposited as iron hydroxides dispersed from high-temperature vents over the axial magma chamber of the East Pacific Rise. In the sediments, the iron hydroxides have reacted diagenetically with siliceous microfossil tests and detrital clays to form $\mathrm{K}$ - and $\mathrm{Fe}$-rich clays with variable $\mathrm{SiO}_{2} / \mathrm{Fe}_{2} \mathrm{O}_{3}$ and $\mathrm{Fe}_{2} \mathrm{O}_{3} / \mathrm{Al}_{2} \mathrm{O}_{3}$ ratios.

The second facies was cored in the active Galapagos Mounds hydrothermal field $21 \mathrm{~km}$ south of the Galapagos Rift. Mounds sediments consist of a capping of Mn oxides and up to 15 meters of green nontronitic mud overlying about 10 meters of carbonate ooze and fresh basalt. The green muds and Mn oxides were precipitated from fluids carrying components derived from alteration of solid basaltic rocks during the early cooling of a consolidated, but thin, oceanic lithosphere. The nontronite has appreciable $\mathrm{SiO}_{2}$ and $\mathrm{MgO}$ not found in the axial iron-hydroxide facies, a high $\mathrm{Fe}_{2} \mathrm{O}_{3} / \mathrm{FeO}$ ratio, virtually no $\mathrm{Al}_{2} \mathrm{O}_{3}$, and a comparatively fixed $\mathrm{SiO}_{2} / \mathrm{Fe}_{2} \mathrm{O}_{3}$ ratio of about 2:1. These geochemical features allow it to be distinguished from the compositionally more variable $\mathrm{K}-\mathrm{Fe}$ montmorillonite of the East Pacific Rise sites which forms diagenetically. On this basis, mounds-type nontronites occur in both Bauer Deep and DOMES Site $\mathrm{C}$ sediments, on the flanks of the East Pacific Rise. The contrasts with the diagenetically produced clays also support the conclusion that the mounds nontronites are direct precipitates from hydrothermal solutions encountering sea water, rather than the products of diagenetic reactions between the solutions and components of the sediments.
\end{abstract}

\section{INTRODUCTION}

During Leg 54, the Glomar Challenger cored a series of holes in two regions of the tropical eastern Pacific, one near $9^{\circ} \mathrm{N}$ on the flanks of the East Pacific Rise, including a site in the Siqueiros fracture zone, the other on the flanks of the Galapagos Rift near the equator at about $86^{\circ} \mathrm{W}$ (Table 1 and Figure 1). The purposes of all these sites were to explore the origin of intermediate and fast-spreading segments of non-rifted oceanic crust, and their subsequent modification by physical and chemical processes at low or high temperatures. At Sites 424 and 425 on the Galapagos Rift, the primary objectives of drilling were geothermal, and site selection was based primarily on measurements of heat flow and near-bottom observations of geothermal phenomena.
In this chapter, we summarize the post-eruptive history of all the sites drilled on Leg 54 . This includes the sedimentary history of the sites and the modification of basement basaltic rocks by interaction with sea water, pore fluids, and possible hydrothermal fluids. The perspective of this report is that oceanic crust, sediments, sea water, and pore fluids constitute a complex system of components that interact to varying degrees depending on such factors as heat flow, sedimentation rate, bottom current activity, structural setting, and depth below the calcite compensation depth. We examined a spectrum of sites in two contrasting settings where the various geothermal phenomena are quite different. Important features of these settings are as follows:

1) Most of the East Pacific Rise sites are thinly sedimented ponds or shallow structural depressions on the 
TABLE 1

Site Locations

\begin{tabular}{|c|c|c|c|c|c|}
\hline Hole & Latitude & Longitude & $\begin{array}{c}\text { Water } \\
\text { Depth } \\
(\mathrm{m})\end{array}$ & $\begin{array}{l}\text { Sediment } \\
\text { Cored } \\
\text { (m) }\end{array}$ & $\begin{array}{c}\text { Basement } \\
\text { Cored } \\
\text { (m) }\end{array}$ \\
\hline \multicolumn{6}{|c|}{ East Pacific Rise } \\
\hline 419 & $08^{\circ} 55.96^{\prime} \mathrm{N}$ & $105^{\circ} 41.17^{\prime} \mathrm{W}$ & 3274 & 35.0 & - \\
\hline $419 \mathrm{~A}$ & $08^{\circ} 55.47^{\prime} \mathrm{N}$ & $105^{\circ} 41.22^{\prime} \mathrm{W}$ & 3274 & 8.0 & - \\
\hline 420 & $09^{\circ} 00.10^{\prime} \mathrm{N}$ & $106^{\circ} 06.77^{\prime} \mathrm{W}$ & 3381 & 118.0 & 28.7 \\
\hline $420 \mathrm{~A}$ & $09^{\circ} 00.50^{\prime} \mathrm{N}$ & $106^{\circ} 06.32^{\prime} \mathrm{W}$ & 3382 & 6.0 & - \\
\hline 421 & $09^{\circ} 01.4 I^{\prime} \mathrm{N}$ & $106^{\circ} 03.68^{\prime} \mathrm{W}$ & 3339 & 19.0 & 19.18 \\
\hline 422 & $09^{\circ} 10.59^{\prime} \mathrm{N}$ & $105^{\circ} 16.27^{\prime} \mathrm{W}$ & 3247 & 49.5 & 23.5 \\
\hline 423 & $09^{\circ} 08.81^{\prime} \mathrm{N}$ & $105^{\circ} 06.57^{\prime} \mathrm{W}$ & 3161 & 38.0 & 15.5 \\
\hline 427 & $08^{\circ} 06.79^{\prime} \mathrm{N}$ & $104^{\circ} 36.35^{\prime} \mathrm{W}$ & 3834 & 70.0 & 28.5 \\
\hline 428 & $09^{\circ} 82.77^{\prime} \mathrm{N}$ & $105^{\circ} 26.14^{\prime} \mathrm{W}$ & 3295 & 39.0 & 15.5 \\
\hline $428 \mathrm{~A}$ & $09^{\circ} 02.77^{\prime} \mathrm{N}$ & $105^{\circ} 26.14^{\prime} \mathrm{W}$ & 3286 & - & 52.5 \\
\hline 429 & $09^{\circ} 02.01^{\prime} \mathrm{N}$ & $106^{\circ} 46.35^{\prime} \mathrm{W}$ & 3406 & 5 & - \\
\hline $429 \mathrm{~A}$ & $09^{\circ} 02.01^{\prime} \mathrm{N}$ & $106^{\circ} 45.87^{\prime} \mathrm{W}$ & 3426 & - & 21.5 \\
\hline \multicolumn{6}{|c|}{ Galapagos Rift } \\
\hline 424 & $00^{\circ} 35.63^{\prime} \mathrm{N}$ & $86^{\circ} 07.82^{\prime} \mathrm{W}$ & 2685 & 37.5 & 38.5 \\
\hline $424 \mathrm{~A}$ & $00^{\circ} 35.33^{\prime} \mathrm{N}$ & $86^{\circ} 07.81^{\prime} \mathrm{W}$ & 2708 & 34.0 & 0.6 \\
\hline $424 B$ & $00^{\circ} 35.82^{\prime} \mathrm{N}$ & $86^{\circ} 07.82^{\prime} \mathrm{W}$ & 2705 & 31.0 & 14.5 \\
\hline $424 C^{\circ}$ & $00^{\circ} 35.93^{\prime} \mathrm{N}$ & $86^{\circ} 07.82^{\prime} \mathrm{W}$ & 2699 & 13.5 & 3.0 \\
\hline 425 & $01^{\circ} 23.68^{\prime} \mathrm{N}$ & $86^{\circ} 04.22^{\prime} \mathrm{W}$ & 2850 & 53.0 & 28.5 \\
\hline
\end{tabular}

flanks of a fast-spreading (6-cm/y. half rate) segment of oceanic crust. Nearly bare rock crops out over perhaps 70 to 90 per cent of the surrounding sea floor. Heat flow measurements scattered throughout the area are mostly low (1.4-3 HFU; Rosendahl and Dorman, this volume), sediments are siliceous nannofossil oozes and marls, and basement ages at the drill sites are between 1.2 and $4.6 \mathrm{~m} . \mathrm{y}$.

2) Site 424 , about $18 \mathrm{~km}$ south of the axis of the Galapagos Rift, consists of four holes drilled into very young basalts (about 600,000 y.) in an area which nevertheless is sedimented to depths of 25 to 30 meters (Klitgord and Mudie, 1974; Lonsdale, 1977a). Basement relief is less than 50 meters, typically less than 10 meters. Basement crops out in less than 20 per cent of the nearby sea floor, and only on prominent fault scarps. This is an area of hypothesized geothermal activity as evidenced by high but variable heat flow (Williams et al., 1974; Williams et al., 1979) and the occurrence of sedimentary mounds of apparent hydrothermal origin (Lonsdale, 1977a) from which hot fluids have been sampled (Corliss et al., 1978). The geothermal system appears to reflect convective circulation of sea water through the crust and sediments (e.g., Williams et al., 1979).

In addition to these major targets, we also drilled Site 425 , about $62 \mathrm{~km}$ north of the Galapagos Rift, on crust about $1.9 \mathrm{~m}$.y. old. The site and surrounding sea floor are uniformly sedimented with siliceous calcareous ooze to depths of 79 meters. Heat flow measurements within $5 \mathrm{~km}$ of the site (Sclater et al., 1974) are moderately high (3.3 HFU) and uniform, corresponding to values predicted for conductive cooling of the underlying oceanic lithosphere. Probably because of high sedimentation rates $(\sim 50 \mathrm{~m} / \mathrm{m} . \mathrm{y}$.$) , a conductive temperature gradient$ is closer to the spreading axis here than at most, if not all, other ridge crests. This allows it to be unusually steep.
We have several objectives in this report. First, we shall discuss evidence for a significant geothermally produced component to sediments we cored on the flanks of the East Pacific Rise near $9^{\circ} \mathrm{N}$ (the Siqueiros fracture zone region) which has come to light as the result of determinations of bulk sediment chemistry (Donnelly, this volume and Appendix). These we shall compare with essentially pure Galapagos Mounds sediments of likely geothermal origin. For the latter, we shall develop especially the viewpoints of the Leg 54 scientific party, which are by no means unanimous, as well as those of various shore-based contributors to this volume. With the mounds area recently re-occupied by the Glomar Challenger during Leg 70 , we see no need to offer a final verdict on these viewpoints, but instead will outline areas where we feel additional study will offer some resolution of divergent opinions. More importantly, we shall emphasize the contrasting settings of East Pacific Rise and Galapagos Rift geothermal activity, as well as offer a computational technique, modified from and partly combining those of Heath and Dymond (1977) and Bischoff et al. (1979a), for delineating varieties of "geothermal" components in largely biogenic pelagic sediments. This will also allow us to illustrate an important difference between the chemistry of hydrothermally produced sediments at the East Pacific Rise and the Galapagos Rift.

\section{LITHOLOGIC VARIATIONS IN EAST PACIFIC RISE SEDIMENTS}

Sediments at Sites 419, 420, 421, 422, 423, 427, and 428 were continuously cored to basaltic basement; they consist primarily of gray-green siliceous calcareous oozes with varying proportions of nannofossils, foraminifers, diatoms, and radiolarians. These are interbedded with reddish brown and dark olive-brown siliceous calcareous clays (Figure 2), particularly toward the tops of the various holes. Sediments at Site 427, in the deepest part of the Siqueiros fracture zone, are more siliceous and are generally dark and pyritiferous, indicating deposition in an environment of more restricted oxygen than the other shallower sites. This may be the result of stagnant bottom water in this deep portion of the fracture zone.

The alternating gray-green and reddish brown lithologies in the several holes are a widespread characteristic of sediments in the eastern equatorial Pacific. This feature was so prevalent in cores recovered in the upper portions of several DSDP sites cored on Legs 8 and 9, that a formation name, the Clipperton, was assigned to this facies (Tracey, Sutton et al., 1971). Our sediments can be considered to be specifically equivalent to the "cyclic member"' of the Clipperton Formation (Hays et al., 1972). Although the principal components of the clay-rich interbeds cored during Legs 8 and 9 were found to be smectites, amorphous iron oxides, and biogenic silica, the origin of so widespread a facies (reaching from the East Pacific Rise to Site 77, some $600 \mathrm{~km}$ to the west), was not resolved by the Leg 9 scientific party (Cook, 1972). 


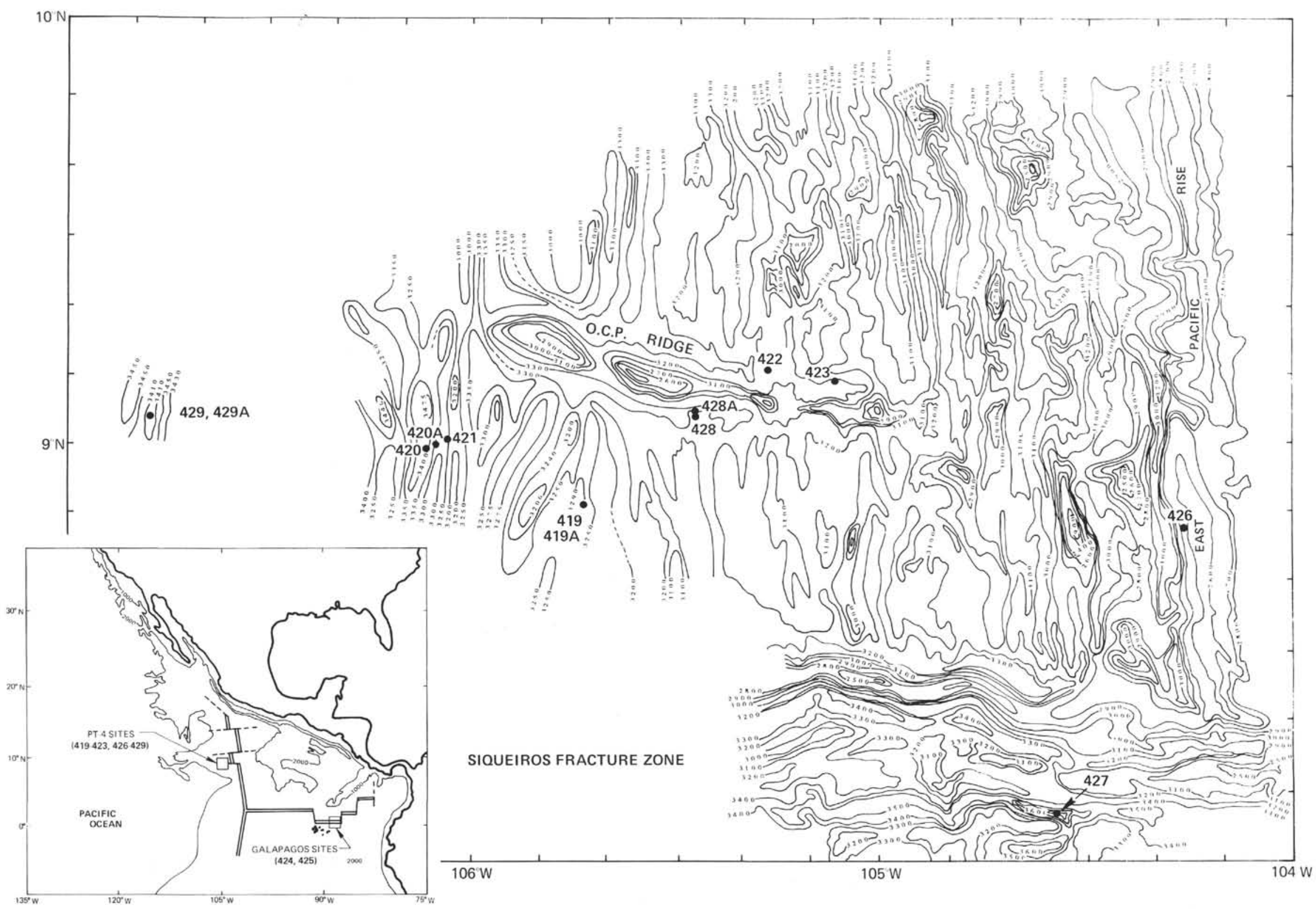

Figure 1. Locations of sites drilled during Leg 54 where sediments were recovered. Bathymetry of region near the Siqueiros fracture zone from Rosendahl and Dorman (this volume). Inset shows locations of sites on the Galapagos Rift. 


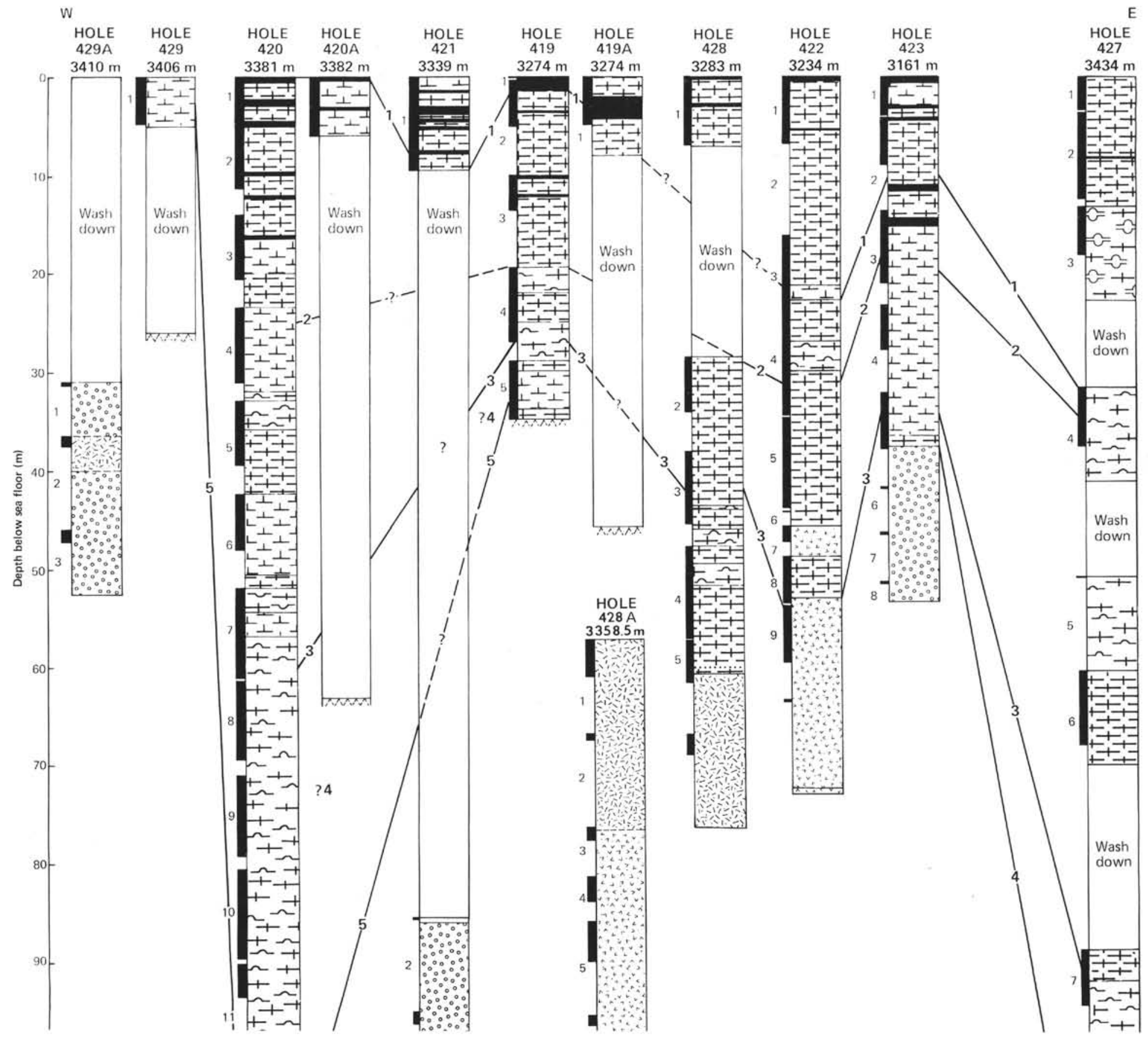




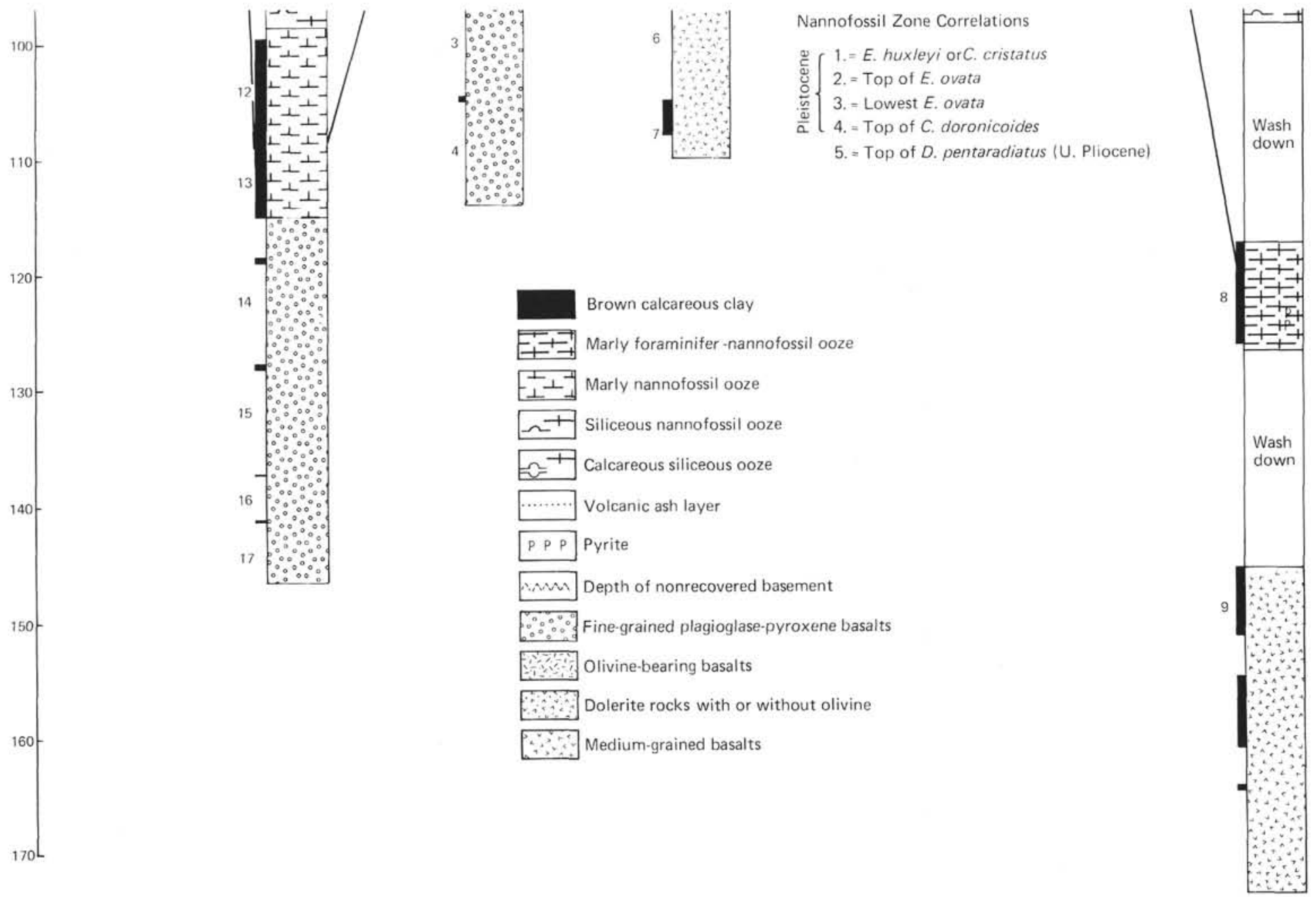

Figure 2. Sediment lithologies versus depth below sea floor at sites drilled on the East Pacific Rise and in the Siqueiros fracture zone during Leg 54. Solid bars to left of each column indicate recovery. Lines between each column indicate microfossil datum levels in each hole. 
On the one hand, the low carbonate abundance, high biogenic silica abundance, and indications of moderate to extensive carbonate dissolution suggested approach of the sites to the lysocline and the possibility that "cycles" of dissolution had occurred. On the other hand, particularly near the rise crest, hydrothermal components, especially the "amorphous iron oxides," might have been added in significant proportions to the sediments, contributing to their brown color.

Partial resolution of this problem has been obtained by correlating abundances of calcium carbonate in DSDP and other cores from the region with detailed biostratigraphy and paleomagnetic fluctuations (e.g., Dunn and Moore, in press). The carbonate fluctuations result from changes in dissolution (Broecker, 1971; Berger, 1973) on the sea floor (Berger, 1967), reflecting changes in the corrosiveness of deep waters. These changes can be correlated from place to place, especially closer to the belt of equatorial high productivity.

In our drilling area, however, correlation of such fluctuations from hole to hole cannot be made because all the targets were small sediment ponds amidst virtually bare igneous outcrops. Redistribution of sediments by currents must have been a factor in accumulating even the small thicknesses of sediments we managed to core. Although detailed lithologic evidence for this is limited by intense drilling disturbance of the cores, several factors support this view:

1) Locally sharp bedding contacts occur between marly and calcareous sediments that are not disturbed by bioturbation;

2) there are local concentrations of siliceous, pyritic, and in one case, vitric sediments, suggestive of size and density sorting by currents, and probable slumping;

3) fragments of basaltic glass, presumably mostly derived from surrounding basement highs by erosion, are an ubiquitous minor component in all the sediments;

4) there are contrasting sedimentation rates at different sites with diastems in some but not in others;

5) there is clear biostratigraphic evidence for intervals of rapid sedimentation in some cores (i.e., redeposition or slumping);

6) there is general lack of correlation of individual marly and calcareous mud zones among holes (Figure 2); and

7) there is lack of agreement between basement ages inferred from magnetic anomalies and the oldest (but still younger) sediments in several holes.

Nevertheless, dissolution effects, especially on foraminifers, are considerable in our drilling area (Krasheninnikov, this volume; Lynts, this volume). We suggest that the probable increased flux of colder, corrosive, bottom waters in the Pleistocene, coupled with a low sedimentation rate, allowed long residence time of sediments on igneous outcrops before redistribution by currents. This promoted locally greater dissolution on the sea floor, following the arguments of Berger (1967). Sediments swept by currents into troughs or hollows may have collected quickly, been buried, and thus been removed from contact with corrosive bottom waters. Hence they preserved their carbonate fraction. Redistri- bution by currents resulted in alternating lithologies that do not correlate from pond to pond.

Therefore, although we view enhanced carbonate dissolution in the Pleistocene as an important factor contributing to the composition of sediments cored on the East Pacific Rise during Leg 54, by itself it cannot explain the alternating lithologies in the upper cores at our sites. We turn now to evaluation of hydrothermal input to these sediments.

\section{CHEMISTRY OF SEDIMENTS CORED AT SITE 420, EAST PACIFIC RISE, AND SITE 425, GALAPAGOS RIFT}

Among East Pacific Rise sites, complete major-oxide chemical compositions have been obtained on sediments only for Site 420, the longest East Pacific Rise sediment section $(120 \mathrm{~m})$ cored on Leg 54 , by Donnelly (this volume and Appendix). Partial major-oxide and trace element abundances have been determined on sediments of several sites by Schrader and Furbish (this volume). Together, these data confirm that there is indeed a major metalliferous component of probable hydrothermal origin in young sediments on the flanks of the East Pacific Rise. Because they make a useful contrast to Site 420, sediments of Site 425 , located $62 \mathrm{~km}$ north of the Galapagos Rift in the Panama Basin, will also be discussed here, also based on analyses by Donnelly (this volume and Appendix). Site 425 sediments, like those of the East Pacific Rise, are mainly siliceous calcareous oozes, but they were deposited at higher rates of accumulation (see Galapagos Site Report), and in close proximity to the equatorial high-productivity belt.

We have chosen two procedures to illustrate tine metalliferous component of East Pacific Rise sedimentsone graphical, the other computational. For the first, sediment compositions were recalculated carbonate-free by assigning all $\mathrm{CaO}$ to $\mathrm{CaCO}_{3}$ (and a minor amount, with $\mathrm{P}_{2} \mathrm{O}_{5}$, to apatite), and normalized to 100 per cent. On Figures 3 through 5, various oxides normalized in this fashion are plotted versus $\mathrm{SiO}_{2}$. Lines drawn from any given point to 100 per cent $\mathrm{SiO}_{2}$ should represent trends of dilution with biogenic silica, having removed the effects of biogenic carbonate in the normalization procedure. The slopes of these lines are negative, as indicated on the figures. A strong correlation of an oxide with one of these dilution lines means that its proportion in the non-biogenic fraction is essentially constant. Some scatter about an "average" dilution trend line means that the oxide was contributed to the sediment by two or more components in which the proportion of the oxide differed, or that the proportion of a single contributing source was variable. Some idea of what these components are can be deduced from the diagrams by comparing fields of data points with potential pure end components. For example, on Figure 3 the field for site 425 analyses trends roughly toward 100 per cent $\mathrm{SiO}_{2}$ on the abscissa from approximately a pure pelagic clay composition. The field for site 420 also trends toward 100 per cent $\mathrm{SiO}_{2}$ on the abscissa, but starting at a composition with higher $\mathrm{Fe}_{2} \mathrm{O}_{3} / \mathrm{SiO}_{2}$ than average pelagic clay. Similarly, we can deduce from Figure 4 that Site 


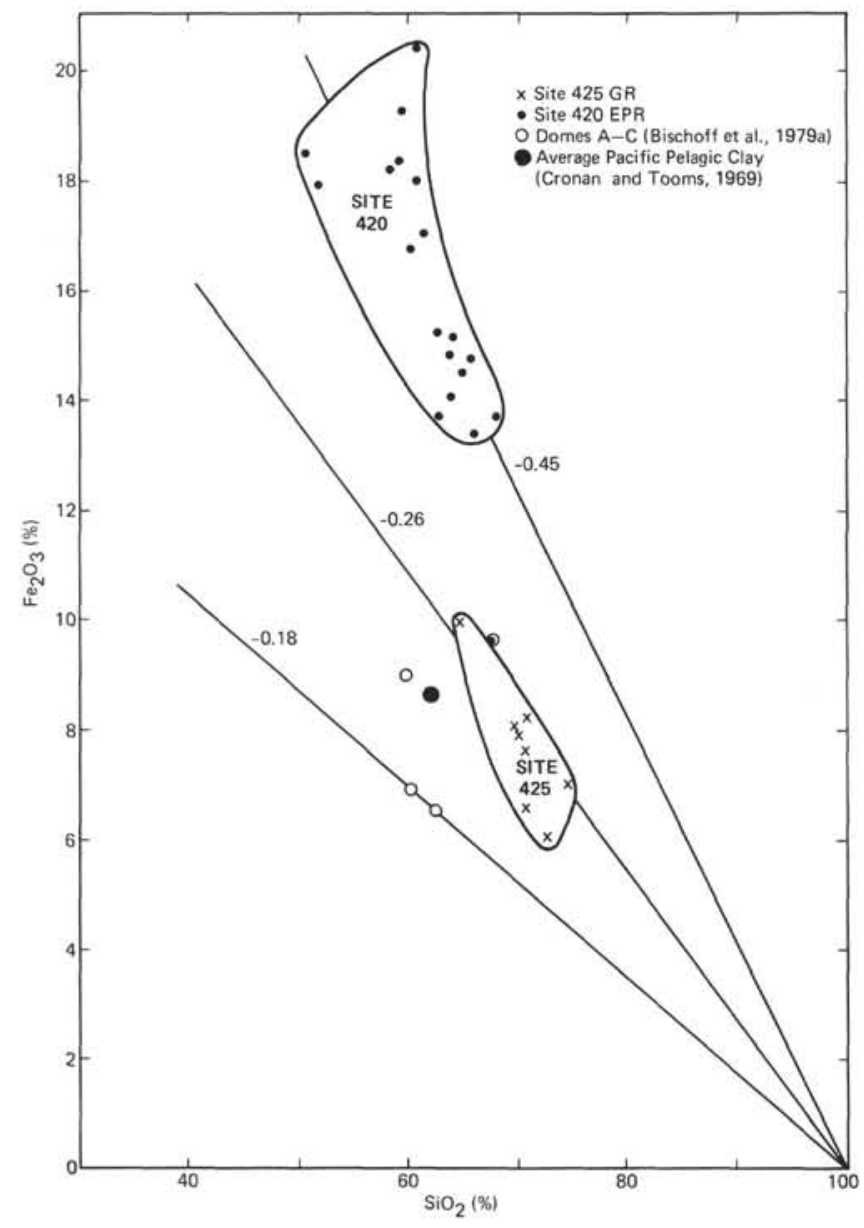

Figure 3. $\mathrm{Fe}_{2} \mathrm{O}_{3}$ versus $\mathrm{SiO}_{2}$ for sediments from Sites 420 (East Pacific Rise) and 425 (Galapagos Rift). Data from Donnelly (this volume, Appendix). Data points are plotted after recalculating sediments $\mathrm{CaCO}_{3}$ free and normalizing to 100 per cent. Fields trend toward 100 per cent $\mathrm{SiO}_{2}$ on abscissa, as indicated by generalized trend lines. Values of negative slopes are indicated for each trend line.

425 sediments fall on an approximate $\mathrm{SiO}_{2}$-dilution trend line which, extrapolated backward, comes very close to average pelagic clay. On the other hand, the component or components thus diluted at Site 420 had lower, and considerably more variable, $\mathrm{Al}_{2} \mathrm{O}_{3}$.

If we suppose that, besides pelagic clay, the other iron-bearing component was an $\mathrm{Al}_{2} \mathrm{O}_{3}$-free iron hydroxide, then the contrast between Site 420 and Site 425 sediments would result from a higher proportion of this component at Site 420 . The plot of $\mathrm{MnO}$ versus $\mathrm{SiO}_{2}$ (Figure 5) shows wide scatter, and no resemblance to the trends for $\mathrm{Fe}_{2} \mathrm{O}_{3}$ or $\mathrm{Al}_{2} \mathrm{O}_{3}$, implying that manganese was supplied to the sediments largely independently of these oxides, apparently as a separate manganese oxide phase or phases. It is much more abundant at Site 420 than Site 425.

It is important to estimate the proportion of various oxides in the sediments that might be added to them from terrigenous sources. Typical oceanic pelagic clay,

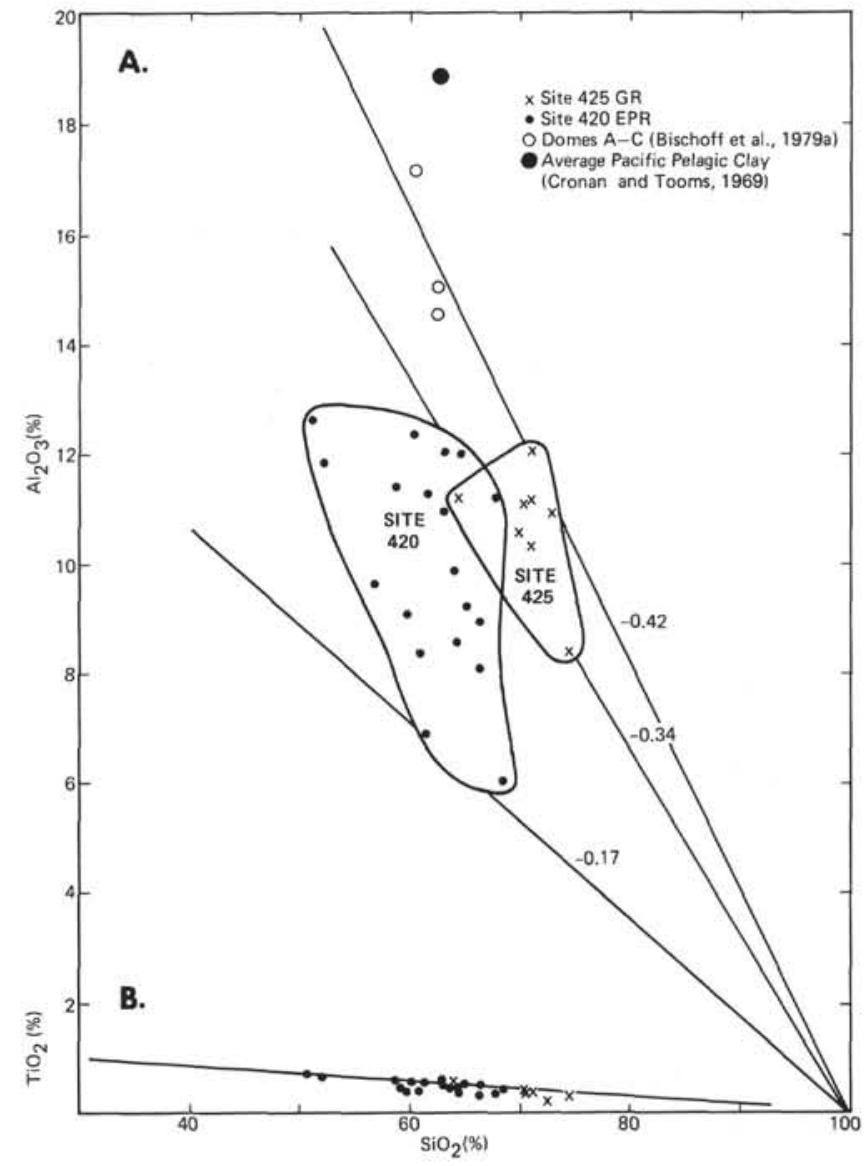

Figure 4. (A) $\mathrm{Al}_{2} \mathrm{O}_{3}$ versus $\mathrm{SiO}_{2}$; (B) $\mathrm{TiO}_{2}$ versus $\mathrm{SiO}_{2}$ for sediments from Sites 420 (East Pacific Rise) and 425 (Galapagos Rift). Data from Donnelly (this volume, Appendix). Data points are plotted after recalculating sediments $\mathrm{CaCO}_{3}$-free and normalizing to 100 per cent. Generalized trend lines and slopes as in Figure 3.

for example, is derived primarily from eolian sources (e.g., Arrhenius, 1963; Griffin and Goldberg, 1963) and appears to have a remarkably uniform composition (Bischoff et al., 1979a). Kaolinite and hydromica both are important constituents of such material (e.g., Timofeev et al., 1978) and both are quite aluminous. This is one reason why metalliferous (i.e., high- $\mathrm{Fe}_{2} \mathrm{O}_{3}$, high$\mathrm{MnO}$, low- $\mathrm{Al}_{2} \mathrm{O}_{3}$ ) sediments found on the crest of the East Pacific Rise are considered to have a hydrothermal, rather than an eolian or "detrital," source (e.g., Boström and Peterson, 1966; Boström et al., 1969; Bischoff et al., 1979a). Enrichments in $\mathrm{Fe}_{2} \mathrm{O}_{3}$ above levels typically found in oceanic pelagic clays, and concomitant depletions in $\mathrm{Al}_{2} \mathrm{O}_{3}$, are consequently good indications of the extent of presumed hydrothermal input to bulk sediment compositions. In both respects, Site 420 clearly has a higher metalliferous component than Site 425 , based on Figures 4 and $6 . \mathrm{TiO}_{2}$, on the other hand, is an oxide in these sediments which is evidently supplied in low but equal proportions by both eolian and hydrothermal sources. It therefore shows most clearly 


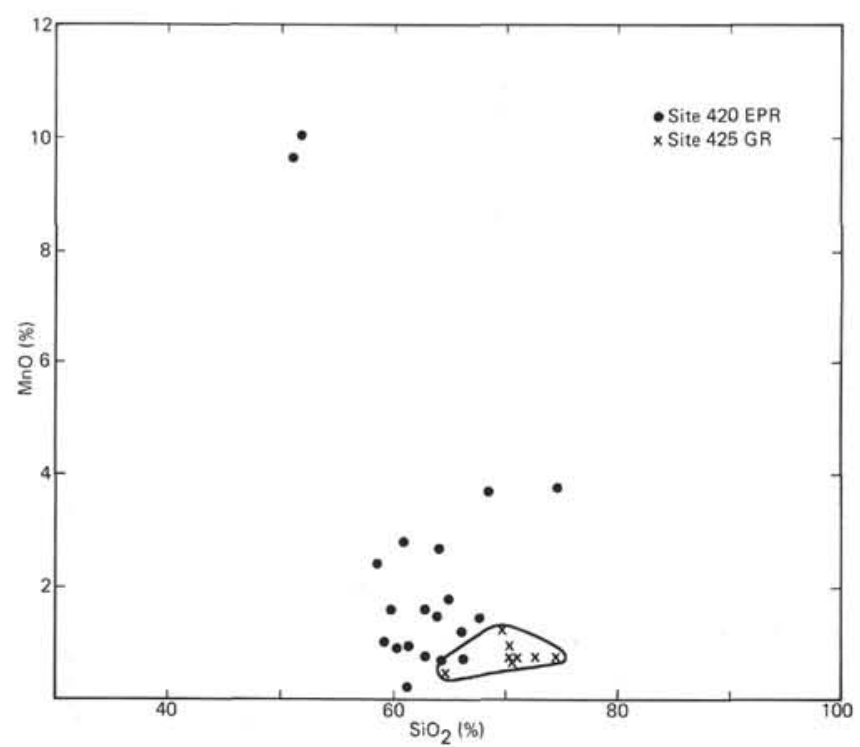

Figure 5. $\mathrm{MnO}$ versus $\mathrm{SiO}_{2}$ for sediments from Sites 420 (East Pacific Rise) and 425 (Galapagos Rift). Data from Donnelly (this volume, Appendix). Data points are plotted after recalculating sediments $\mathrm{CaCO}_{3}$ free and normalizing to 100 per cent.

the effect of biogenic silica dilution (Figure 4B). The dispersion of $\mathrm{Fe}_{2} \mathrm{O}_{3}$ and $\mathrm{Al}_{2} \mathrm{O}_{3}$ away from silica dilution trends on these diagrams can therefore be taken to represent variable metalliferous input to the sediments, more pronounced for Site 420 than Site 425 . Figure 6 summarizes the $\mathrm{Fe}_{2} \mathrm{O}_{3}$ and $\mathrm{Al}_{2} \mathrm{O}_{3}$ contrast between Sites 420 and 425; only one Site 420 sample has $\mathrm{Fe}_{2} \mathrm{O}_{3}$ as low as any of the Site 425 samples, and several of the latter have $\mathrm{Fe}_{2} \mathrm{O}_{3} / \mathrm{Al}_{2} \mathrm{O}_{3}$ virtually identical to Pacific pelagic clay (Bischoff et al., 1979a).

The computational approach involves a combination of two procedures, both of which are based on types of normative calculations for eastern Pacific sediments. The first is the method of Heath and Dymond (1977), only here modified for oxide rather than elemental abundances. The procedure is to calculate for each oxide those proportions which are detrital (i.e., eolian), hydrothermal, biogenic, or hydrogenous in origin using assignments based on geochemically plausible assumptions. The basic equations are Equations 1-8 in Heath and Dymond (1977), but modified to oxide format. Without Ni data, however, the hydrogenous component (based on their Equation 9) cannot be explicitly calculated. This is not important for $\mathrm{SiO}_{2}, \mathrm{Al}_{2} \mathrm{O}_{3}$, and $\mathrm{Fe}_{2} \mathrm{O}_{3}$, since the method assumes that no fraction of these oxides is hydrogenous in origin. Of critical importance here are the assumptions that both $\mathrm{Fe}_{2} \mathrm{O}_{3}$ and $\mathrm{Al}_{2} \mathrm{O}_{3}$ consist solely of hydrothermal and detrital components, and that detrital $\mathrm{Fe}_{2} \mathrm{O}_{3} / \mathrm{Al}_{2} \mathrm{O}_{3}$ is fixed at a ratio comparable to that of typical pelagic clay ( 0.567 for the oxide ratio, indicated on Figure 6). Using this procedure, the proportions of detrital and hydrothermal $\mathrm{Fe}_{2} \mathrm{O}_{3}$, and detrital, hydrothermal, and biogenic $\mathrm{SiO}_{2}$, are plotted versus depth for both Sites 420 and 425 (Figure 7). Biogenic $\mathrm{SiO}_{2}$ is determined by difference after hydrothermal and

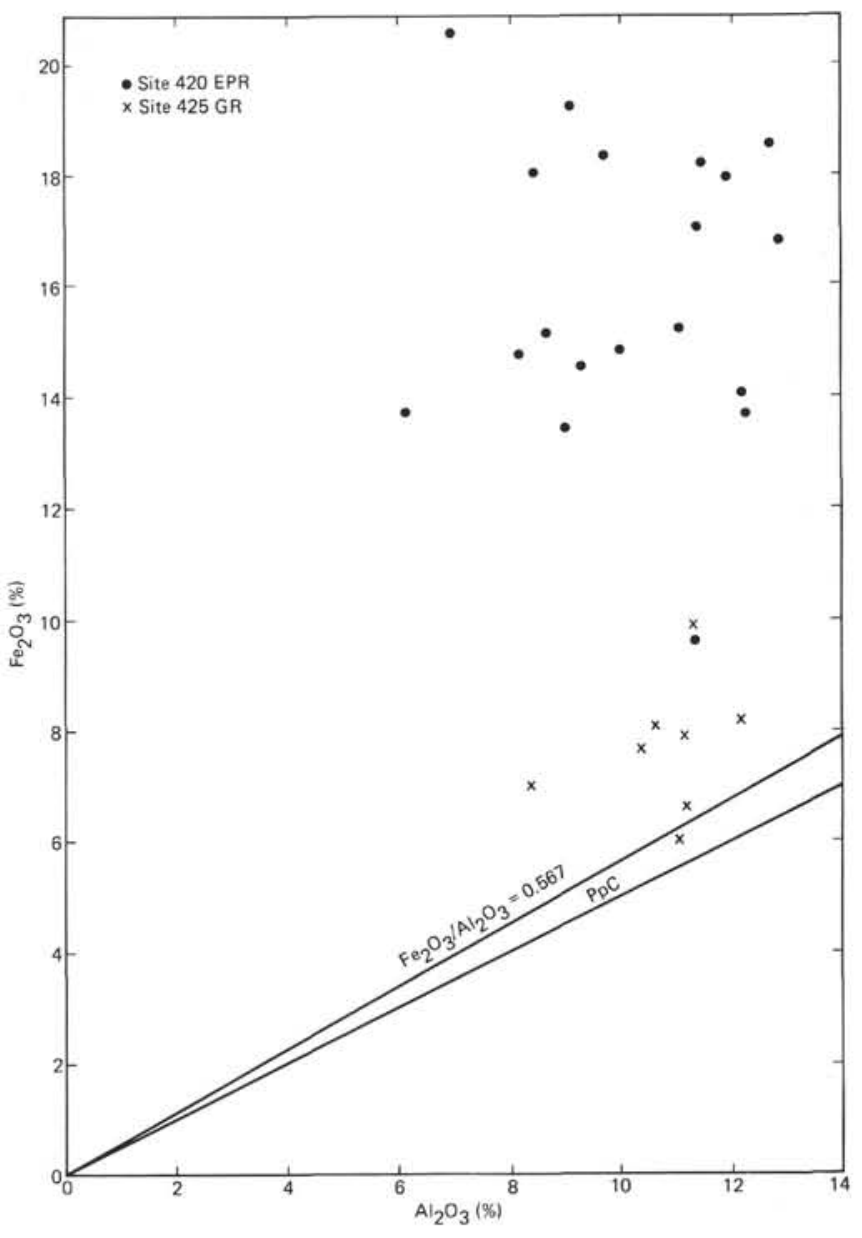

Figure 6. $\mathrm{Fe}_{2} \mathrm{O}_{3}$ versus $\mathrm{Al}_{2} \mathrm{O}_{3}$ for sediments from Site 420 (East Pacific Rise) and 425 (Galapagos Rift). Data from Donnelly (this volume, Appendix). Data points are plotted after recalculating sediments $\mathrm{CaCO}_{3-}$ free and normalizing to 100 per cent. Lines show ratios of $\mathrm{Fe}_{2} \mathrm{O}_{3} / \mathrm{Al}_{2} \mathrm{O}_{3}$ for average DOMES pelagic clay (= 0.567; Bischoff et al., 1979) and Cronan's (1972) average Pacific pelagic clay $(P p C)$.

detrital components have been calculated. This figure illustrates that hydrothermal $\mathrm{Fe}_{2} \mathrm{O}_{3}$ has been a major fraction (50-80\%) of all the $\mathrm{Fe}_{2} \mathrm{O}_{3}$ in Site 420 sediments regardless of how diluted with biogenic carbonate and $\mathrm{SiO}_{2}$. With the exception of one sample, the proportion of hydrothermal $\mathrm{Fe}_{2} \mathrm{O}_{3}$ shows a general increase with depth, and is over 80 per cent of the total $\mathrm{Fe}_{2} \mathrm{O}_{3}$ in the deepest sample analyzed. The proportion of hydrothermal $\mathrm{Fe}_{2} \mathrm{O}_{3}$ in Site 425 sediments, however, is much lower $(2-38 \%)$, consistent with the qualitative impression given by Figure 4 .

Without Ni data, as already mentioned, there is no way to estimate what proportion of $\mathrm{MnO}$ is hydrothermal and what proportion is hydrogenous. The detrital proportion is trivial. Heath and Dymond (1977) indicate that $\mathrm{Co}$ would be a somewhat better element than $\mathrm{Ni}$ to use in estimating hydrogenous abundances of other elements, based on ratios of these elements to Co in hydrogenous material. Although we also lack Co data on the 


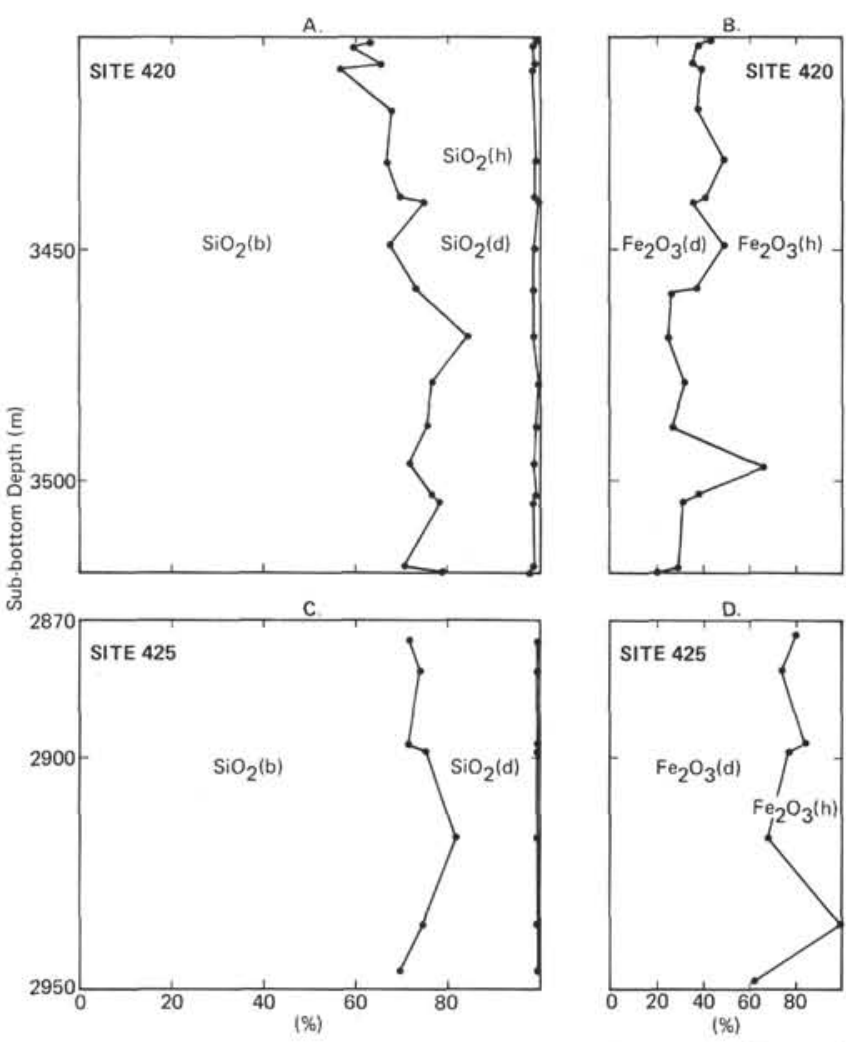

Figure 7. Percentage of biogenic (b), detrital (d), and hydrothermal (h) $\mathrm{SiO}_{2}$ versus depth, and detrital (d) and hydrothermal (h) $\mathrm{Fe}_{2} \mathrm{O}_{3}$ versus depth, Sites 420 ( $A$ and $B$ ) and 425 (C and D) computed using the procedure of Heath and Dymond (1977). The scale for $\mathrm{SiO}_{2}$ is expanded to show the low hydrothermal $\mathrm{SiO}_{2}$ at both sites calculated by this procedure. Data from Donnelly (this volume, Appendix).

specific samples plotted on Figures 3 through 6, Schrader and Furbish (this volume) measured Co on a number of samples from several sites drilled on Leg 54. Their data show no correlation between low Co abundances (44-339 ppm) and usually very high $\mathrm{Fe}$ or $\mathrm{Mn}$ values. Co is nearly as low as in demonstrably hydrothermal sediments at Site 424 (e.g., Natland et al., 1979; Hoffert et al., this volume). By the assumptions of Heath and Dymond (1977), this implies that most MnO in the Site 420 sediments is hydrothermal in origin.

Somewhat different geochemical relations between $\mathrm{SiO}_{2}, \mathrm{Fe}_{2} \mathrm{O}_{3}$, and $\mathrm{MnO}$ are indicated by the computational procedure of Bischoff et al. (1979a). This, too, involves assigning proportions of various oxides to pelagic clay (here an explicit average composition based on sediment analyses is assumed), and to an average manganese nodule composition for the DOMES area they investigated. This area, on Miocene East Pacific Rise crust northwest of the Siqueiros region, is of some interest here because the oldest metalliferous sediment at the DOMES sites appear to have been deposited very near the crest of the rise at an almost identical paleolatitude as the Leg 54 sediments (Bischoff et al., 1979b). Although most of the DOMES sediments conform closely to pelagic clay and hydrogenous manganese nodule components, DOMES Site $\mathrm{C}$ has a distinctive iron-rich metalliferous component inferred to have been hydrothermal in origin.

The procedure of Bischoff et al. (1979a) involves calculating "excess" $\mathrm{Fe}_{2} \mathrm{O}_{3}, \mathrm{SiO}_{2}$, and other oxides. Excess $\mathrm{Fe}_{2} \mathrm{O}_{3}$, for example, is $\mathrm{Fe}_{2} \mathrm{O}_{3}$ not in pelagic clay, as determined for any particular sediment bulk composition using the ratio of $\mathrm{Fe}_{2} \mathrm{O}_{3} / \mathrm{Al}_{2} \mathrm{O}_{3}$ in pelagic clay, plus bulk $\mathrm{Fe}_{2} \mathrm{O}_{3}$ and $\mathrm{Al}_{2} \mathrm{O}_{3}$ (this assumption is identical to that of Heath and Dymond, 1977). Hydrothermal $\mathrm{Fe}_{2} \mathrm{O}_{3}$, similarly, is excess $\mathrm{Fe}_{2} \mathrm{O}_{3}$ minus the proportion of iron combined with manganese in average DOMES manganese nodules (excess $\mathrm{Fe}_{2} \mathrm{O}_{3}-0.32 \mathrm{MnO}$ ). This assumption entails that all $\mathrm{MnO}$ be considered hydrogenous. We have already argued that at Site 420 especially, most of it is hydrothermal. But with no Co or Ni data, we cannot calculate hydrogenous $\mathrm{MnO}$. Therefore, hydrothermal $\mathrm{Fe}_{2} \mathrm{O}_{3}$ may be underestimated by 0.1 to 1.2 per cent for most samples, and possibly by greater than 3 per cent for the two samples with over 9 per cent normalized $\mathrm{MnO}$. This does not seriously affect conclusions reached later in this section, since hydrothermal $\mathrm{Fe}_{2} \mathrm{O}_{3}$ is conservatively estimated in all cases.

When excess $\mathrm{SiO}_{2}$ (i.e., not in a pelagic clay component) is plotted against the calculated hydrothermal $\mathrm{Fe}_{2} \mathrm{O}_{3}$, important features of tropical eastern Pacific sediments emerge (Figure 8). Site 425 sediments have little hydrothermal $\mathrm{Fe}_{2} \mathrm{O}_{3}$ and high excess $\mathrm{SiO}_{2}$, the hallmark of biogenic $\mathrm{SiO}_{2}$. In these respects, they resemble two of the three DOMES sites (compare with Figure 8 of Bischoff et al., 1979a). Site 420 sediments clearly include some also enriched in biogenic silica, but others lie near the trend line for Bauer Deep metalliferous sediments, as do a fair proportion of sediments analyzed from DOMES Site C. Two of the samples, however, have excess $\mathrm{SiO}_{2}$ below that of Bauer Deep-DOMES Site C sediments, implying an unusual enrichment in $\mathrm{Fe}_{2} \mathrm{O}_{3}$.

The explanation for the rather fixed ratio of hydrothermal $\mathrm{Fe}_{2} \mathrm{O}_{3}$ /excess $\mathrm{SiO}_{2}$ in Bauer Deep and DOMES Site $\mathrm{C}$ sediments is important to consider here. Bischoff et al. (1979b) proposed that diagenetic reaction between hydrothermal amorphous iron oxides and biogenic silica produced a clay mineral in the DOMES Site $\mathrm{C}$ sediments with a very specific composition. On the other hand, we note that the ratio of $\mathrm{Fe}_{2} \mathrm{O}_{3} / \mathrm{SiO}_{2}$ in green hydrothermal nontronites we cored at Site 424 in the Galapagos Mounds hydrothermal field (which we shall discuss in more detail later) is the same as the ratio for the Bauer Deep and DOMES Site C sediments, as indicated on Figure 8. In fact, Bischoff et al. (1979b) noted that a fair amount of $\mathrm{MgO}$ was supplied hydrothermally to DOMES Site C. The values of $\mathrm{MgO}$ for Site 424 green nontronites are remarkably similar to DOMES Site C values, especially if calculated $\mathrm{MnO}$-free (Table 2). We shall later argue, as others have, that the mounds-type nontronite is a direct precipitate from hydrothermal solutions that has both elevated $\mathrm{Fe}_{2} \mathrm{O}_{3}$ and appreciable $\mathrm{SiO}_{2}$. It therefore represents a facies distinct from the rise-crest iron hydroxide facies, which has very low $\mathrm{SiO}_{2}$. Figure 8, then, can be taken as evidence that a mounds-type nontronite may be the iron-bearing hydro- 


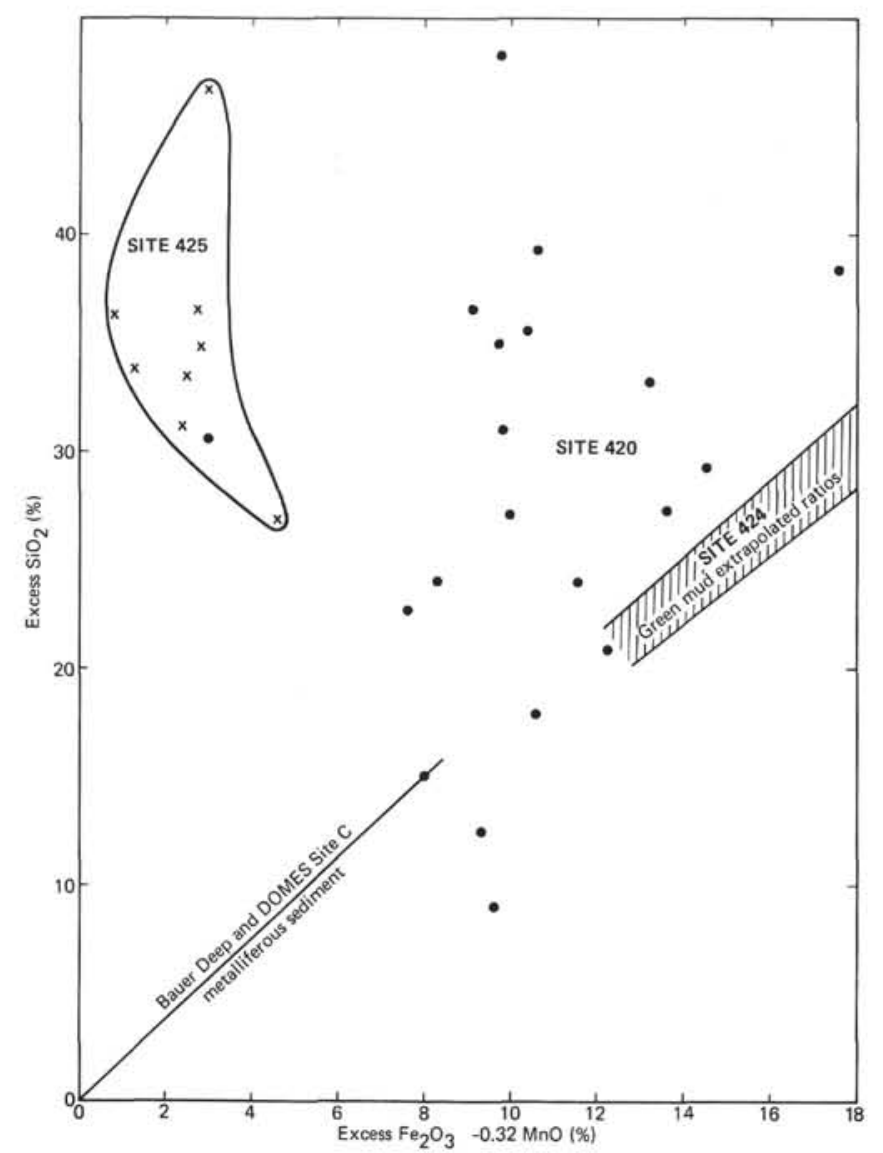

Figure 8. Excess $\mathrm{SiO}_{2}$ versus excess $\mathrm{Fe}_{2} \mathrm{O}_{3}-0.32 \mathrm{MnO}$ for sediments from Sites 420 (East Pacific Rise) and 425 (Galapagos Rift). Data from Donnelly (this volume, Appendix). Data points calculated from procedure of Bischoff et al. (1979). Sediment totals were first normalized to 100 per cent. Trend lines for Bauer Deep and DOMES Site C metalliferous sediment from Bischoff et al. (in press) and Site 424 green nontronitic mud (Hekinian et al., 1978) are also shown.

TABLE 2

Calculated Average Compositions of Site 424 Green Muds (Table 3) and Metalliferous Sediment Fractions of DOMES Site $\mathrm{C}$ and Bauer Deep

\begin{tabular}{|c|c|c|c|c|}
\hline & 1 & 2 & 3 & 4 \\
\hline $\mathrm{SiO}_{2}$ & 60.4 & 59.2 & 57.0 & $(59.4)$ \\
\hline $\mathrm{Fe}_{2} \mathrm{O}_{3}$ & 35.1 & 28.9 & 33.3 & (34.7) \\
\hline $\mathrm{MgO}$ & 4.4 & 7.3 & 5.8 & $(6.0)$ \\
\hline $\mathrm{MnO}$ & 1 & 4.6 & 4.0 & - \\
\hline$\Sigma$ & 100 & 100 & 100 & \\
\hline
\end{tabular}

Notes:

$1=$ Green mud, Site 424 (Table 3).

$2=$ Average DOMES (Bischoff et al., 1979b).

3 = Bauer Deep average (Bischoff and Rosenbauer, 1977).

$4=$ Bauer Deep average calculated $\mathrm{MnO}$-free. thermal component both at Bauer Deep and DOMES Site C.

We shall return to this point later. At present, however, we wish to emphasize that the occurrence of a hydrothermal facies with appreciable $\mathrm{SiO}_{2}$ means that the proportion of hydrothermal $\mathrm{SiO}_{2}$ calculated using the procedure of Heath and Dymond (1977), and shown on Figure 7, could be seriously underestimated without independent verification that iron hydroxides are the predominant hydrothermal component, rather than a moundstype iron nontronite.

At Site 420, we have such verification. Iron hydroxides have been identified among Sites 420 sediments by $\mathrm{X}$-ray diffraction techniques and by microscopic observation (Rateev et al., this volume). These authors also identified a type of iron-rich montmorillonite as the predominant clay mineral in East Pacific Rise sediments cored on Leg 54. The iron montmorillonite could be distinguished readily from common (detrital) montmorillonite, because it has prominent X-ray diffractogram peaks that disappear after heating in 10 per cent $\mathrm{HCl}$ at $80^{\circ} \mathrm{C}$ for one hour. Other detrital minerals in the clay fraction are illite $(20 \%-35 \%)$, kaolinite $(10 \%-20 \%)$, and chlorite $(<5 \%)$. The compositions of the iron montmorillonite at Site 420 obtained by Rateev et al. (this volume) have quite variable $\mathrm{SiO}_{2} / \mathrm{Al}_{2} \mathrm{O}_{3}$ ratios (4.23-8.56), but they are still clearly distinct from Site 424 green nontronites where this ratio is $>32 . \mathrm{Fe}_{2} \mathrm{O}_{3}$ / $\mathrm{Al}_{2} \mathrm{O}_{3}$ in the Site 420 iron montmorillonites ranges from 1.44 to 2.01 , values considerably lower than in the green nontronites of Site 424 (>14). However, at Site 420, the $\mathrm{Fe}_{2} \mathrm{O}_{3} / \mathrm{Al}_{2} \mathrm{O}_{3}$ ratio of the iron montmorillonites is comparable only to the lowest bulk sediment values. This implies that there is additional iron in many of the sediments not in clay minerals at all, but in some form of iron hydroxide. It is important in this respect that the compositions of Site 420 iron montmorillonites reported by Rateev et al. (this volume) do not lie on a mixing line on Figure 8 between Pacific pelagic clay and Site 424 green nontronites. Therefore no similar nontronite component exists at all in the Site 420 sediments.

The origin of the iron montmorillonite appears to be authigenic. Rateev et al. (this volume) describe its occurrence as filling cavities in radiolarian skeletons, replacing worm burrows, forming nodules or globules that are surrounded on their periphery by earthy $\mathrm{Mn}$ compounds, and interestingly, resulting from decomposition of "vitroclastic" basaltic materials. They identify phillipsite, hematite, and Mn compounds associated with iron montmorillonite in X-ray diffractograms.

Excess $\mathrm{Fe}_{2} \mathrm{O}_{3}$ is plotted versus $\mathrm{MnO}$ on Figure 9. There are no samples from either Sites 420 or 425 which resemble average DOMES manganese nodules, based on this diagram. $\mathrm{MnO}$ therefore does not seem to have a hydrogenous origin, consistent with our earlier deduction based on low Co in the sediments. It therefore is primarily hydrothermal in origin. The lack of correlation with excess $\mathrm{Fe}_{2} \mathrm{O}_{3}$ shows that deposition of manganese oxides was effectively decoupled from precipitation of iron-rich hydrothermal sediments. 


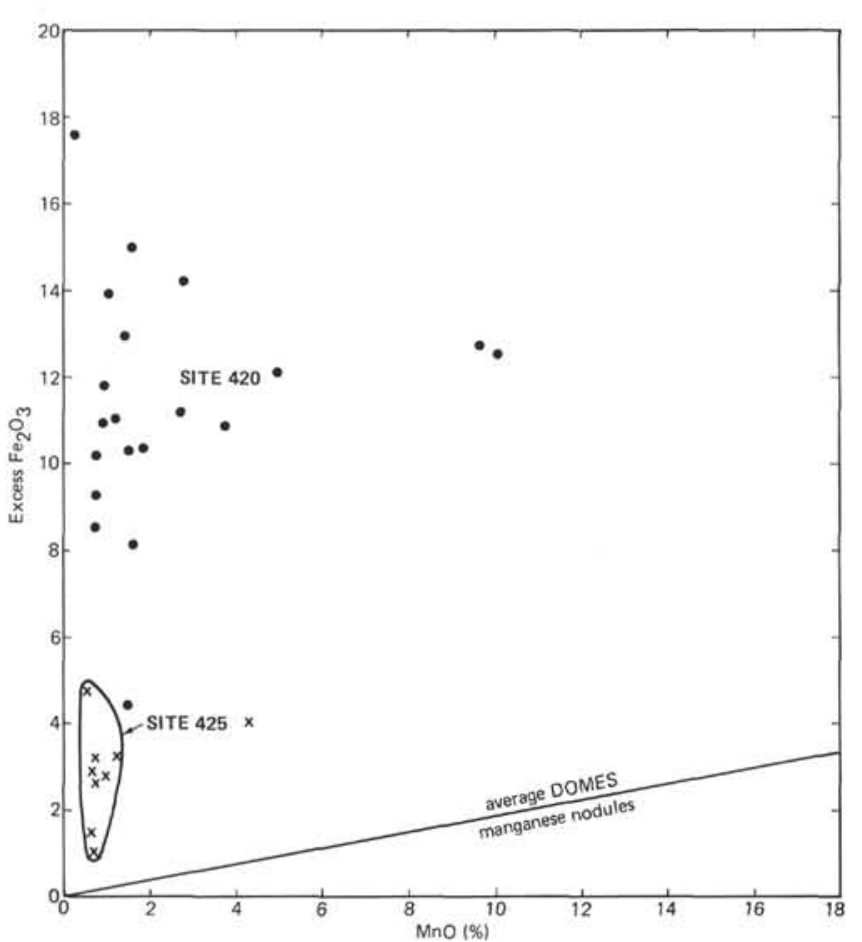

Figure 9. Excess $\mathrm{Fe}_{2} \mathrm{O}_{3}$ versus $\mathrm{MnO}$ for sediments from Sites 420 (East Pacific Rise) and 425 (Galapagos Rift). Data from Donnelly (this volume, Appendix). Excess $\mathrm{Fe}_{2} \mathrm{O}_{3}$ was calculated following Bischoff et al. (1979). Average DOMES hydrogenous manganese nodule ratio is indicated by the line. Data points were plotted after sediment totals were first normalized to 100 per cent.

Heath and Dymond (1977) argued that most of the iron and manganese in the eastern Pacific sediment samples which they examined were originally deposited as poorly crystallized ferro-manganese hydroxides. These later reacted with silica, mainly biogenic, to form iron hydroxides, well-crystallized manganese oxides (mainly todorokite), and iron-rich smectites. Such reactions appear to explain the mineral assemblages in our Leg 54 East Pacific Rise sediments, and are consistent with the lithologic observations of Rateev et al. (this volume). Poor preservation of radiolarians in many East Pacific Rise sediment samples (Goll, this volume) could well have resulted from such reactions. Rateev et al. (this volume), however, place the origin of the iron montmorillonite not in reaction with biogenic silica, but in decomposition of basaltic glass which they observed microscopically. We cannot support this view for the bulk of the iron montmorillonites, since $\mathrm{TiO}_{2}$ in typical East Pacific Rise basaltic glasses ranges from 0.9 to 2.2 per cent (Natland and Melson, this volume), values far in excess of the levels observed in sediments calculated $\mathrm{CaCO}_{3}$-free (Figure 3), in which values are mainly those of detrital components (i.e., pelagic clay diluted with biogenic silica). Volcanic glass therefore can only be a minor component of the sediments. On the other hand, some reaction between iron hydroxides and detrital clays must also occur, given the high $\mathrm{Al}_{2} \mathrm{O}_{3}$ and low $\mathrm{Fe}_{2} \mathrm{O}_{3} / \mathrm{Al}_{2} \mathrm{O}_{3}$ of the clay fractions analyzed by Rateev et al. (this volume).

Site 420 , then, is a clear example of the course that diagenetic reaction between iron hydroxides and siliceous components in the sediments should take. Most importantly, it does not produce a clay mineral with a specific composition. We are therefore skeptical of a diagenetic origin for clay minerals with a fixed $\mathrm{Fe}_{2} \mathrm{O}_{3}$ / $\mathrm{SiO}_{2}$ ratio at DOMES Site $\mathrm{C}$ and Bauer Deep as argued by Bischoff et al. (1979b). Heath and Dymond (1977) also concluded that diagenetic reactions involving iron hydroxides and siliceous components occurred in the Bauer Deep sediments, but only after adopting the assumption that hydrothermal $\mathrm{SiO}_{2}$ was very low. $\mathrm{Al}$ though this might be true for most of the equatorial $\mathrm{Pa}$ cific sediments examined by Heath and Dymond, our analysis here indicates that this need not be the case for the Bauer Deep.

In summary, although there is a type of iron montmorillonite in Leg 54 East Pacific Rise sediments, much, if not all, of it appears to form diagenetically by reaction between $\mathrm{Fe}-\mathrm{Mn}$ hydroxides and biogenic silica, detrital clays, and minor volcanic glass. This iron montmorillonite differs chemically from considerably less aluminous green ferruginous smectites that occur in the Galapagos Mounds geothermal field, and evidently, at the Bauer Deep and DOMES Site C. The original hydrothermal sediment among the Leg 54 East Pacific Rise sediments was primarily iron and manganese hydroxides.

\section{ALTERATION IN EAST PACIFIC RISE BASALTS}

Alteration in the drilled East Pacific Rise basalts is confined mainly to distinctive 1 - to 3 -cm-wide alteration rinds which appear to have paralleled fracture and flowsurfaces. Even in these rinds, combined water $\left(\mathrm{H}_{2} \mathrm{O}^{+}\right)$is rarely more than 1 per cent (Humphris et al., alteration chapter, this volume). The principal alteration minerals are smectites, with lesser calcite, and rarely zeolite (phillipsite). Chlorite or other high-temperature alteration minerals are absent. Chemically, the principal effects of the alteration appear to have been (1) an increase in the ratio $\mathrm{Fe}_{2} \mathrm{O}_{3} / \mathrm{FeO}$ in the rinds compared with the fresher cores, and (2) uptake of $\mathrm{K}_{2} \mathrm{O}$ from sea water (Humphris et al., alteration chapter, this volume). Within the basalts, the mineral most affected by alteration is olivine, which tends to be partly or completely replaced in alteration rinds by smectites and iron hydroxides. Glass is also partially replaced by smectites of various colors (bright green, light brown, bright orange-brown). Clay minerals also form fracture-surface coatings and fill vesicles. The most abundant clay mineral, which replaces olivine and groundmass, is enriched in $\mathrm{K}$ and $\mathrm{Fe}$ (Humphris et al., alteration chapter, this volume). Saponite replaces plagioclase in some samples from Site 429. Titanomagnetites are also affected by oxidation, which releases a considerable amount of $\mathrm{Fe}$ from the 
spinel structure. Petersen and Roggenthen (this volume) have demonstrated that most titanomagnetite oxidation on the East Pacific Rise and the Mid-Atlantic Ridge occurs within less than three million years of extrusion and speculate that this could be an important source of the iron found in rise-crest hydrothermal precipitates. The final product of this alteration is cation-deficient titanomaghemite. These authors infer that oxidation occurred at low temperatures-most likely, bottom-water temperatures.

Small and narrow vein sulfides occur in basalts only at Sites 427 and 428 . Pyrite also occurs as one of several vesicle filling secondary phases, including clays, iron oxyhydroxides, and calcite (Schrader and Furbish, this volume). It is not possible to say whether these vesiclefilling sulfides are deuteric or hydrothermal in origin. At Site 428 , vein sulfides (pyrite and chalcopyrite) are also associated with oxidized titanomagnetite. Schrader and Furbish (this volume) suggest that the iron released from the oxide minerals during their oxidation (e.g., Petersen and Roggenthen, this volume) reacted with sulfate-bearing hydrothermal solutions to produce both pyrite and iron hydroxide. There are no data as yet which would indicate what the temperatures of these solutions might have been.

These small indications of alteration notwithstanding, it is evident that the extent of alteration in these surficial basalts could contribute only a trivial fraction to the significant hydrothermal component in the sediments. The source of these components must be, overall, considerably deeper in the crust and involve a much larger volume of rock (or magma) than is represented by the basalts we cored. Full assessment of East Pacific Rise geothermal activity still awaits a comprehensive deep crustal drilling program.

\section{GEOTHERMAL ACTIVITY AND ASSOCIATED SEDIMENTS NEAR THE GALAPAGOS RIFT}

The Galapagos Spreading Center (Lonsdale and Klitgord, 1978), has been the focus of a considerable effort to understand sea-floor geothermal processes by means of direct observations using submersibles (Corliss et al., 1978), deep-tow studies (Lonsdale, 1977a; Weiss et al., 1977), heat flow measurements (Sclater and Klitgord, 1973; Williams et al., 1974; Detrick et al., 1974; Williams et al., 1979), and, during Leg 54, drilling (Hekinian et al., 1978; Natland et al., 1979; this volume). Most of this activity has been concentrated in two areas: the axis of the Galapagos Rift near $1^{\circ} \mathrm{N}, 86^{\circ} \mathrm{W}$, and the Galapagos Mounds geothermal field, located between 17 and $22 \mathrm{~km}$ south of this portion of the rift (Figure 10).

It is a matter of some historical interest that the first observations of the mounds deposits using near-bottom sonar devices attached to the deep-tow device of Scripps Institution's Marine Physical Laboratory produced essentially the correct interpretation of their hydrothermal origin (Klitgord, 1974; Klitgord and Mudie, 1974). This was achieved without a color bottom photograph, without a bottom sample, and without heat-flow measurements of the mounds themselves. This chance observa-

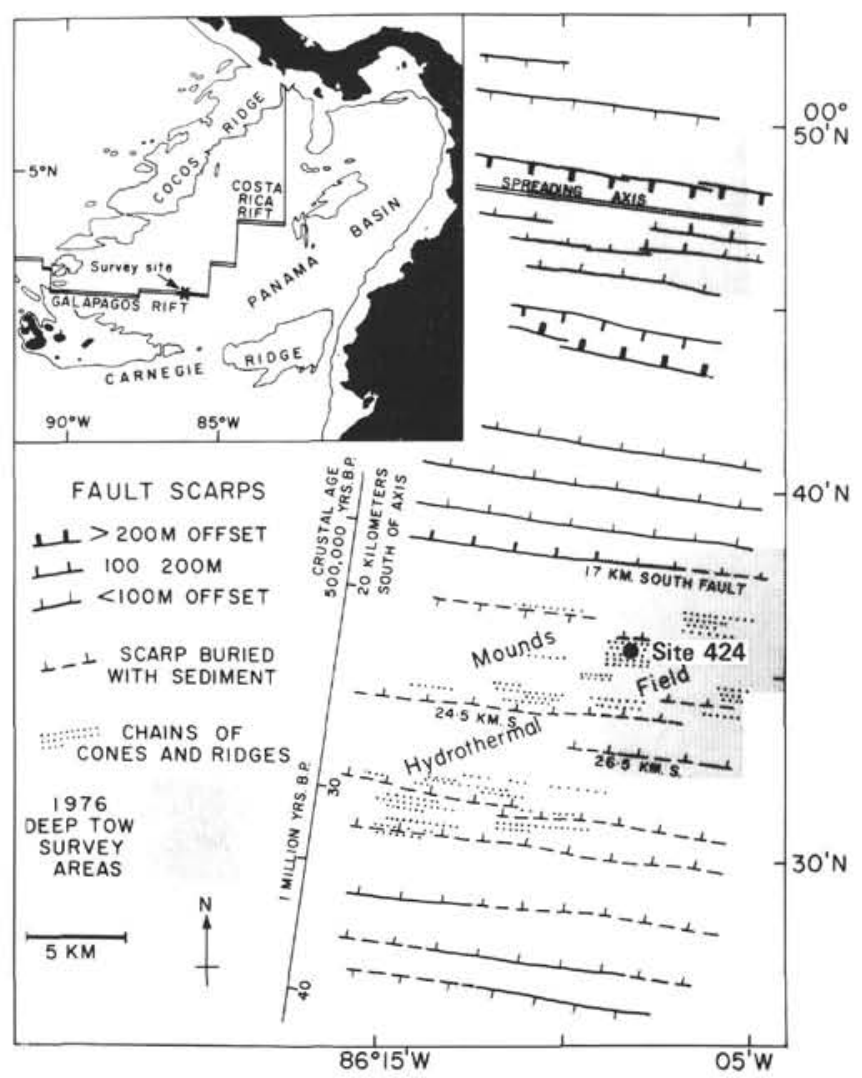

Figure 10. Setting of the Galapagos Mounds geothermal field on the south flank of the Galapagos Rift, from Lonsdale (1977a) with permission.

tion, obtained during an investigation of crustal geomorphology, structure, magnetics, and spreading history, prompted all the activity that has occurred since, and has made the Galapagos Rift and environs one of the most completely studied portions of sea floor on earth.

The second deep-tow survey of the mounds region (Lonsdale, 1977a) was designed specifically to investigate the mounds, and led to the first integrated hypothesis of their origin. The mounds are arrayed in rows, ridges, and strips above small (1-to 20-m) offsets in the basement basalts that were produced by faulting. Lonsdale (1977a) proposed that the mounds are direct precipitates from hydrothermal fluids which leak out of the basement rocks along these faults. Three aspects of the mounds deposits revealed by the deep-tow survey indicated very recent or even active present-day addition of materials to the mounds. These were (1) upward arching of two reflectors in the regional sediment blanked in the immediate vicinity of the mounds (Figure 11); (2) steepsloped, even pinnacle-like mound geomorphologies, not degraded by gravitational collapse of soft and brittle materials, and (3) absence of all but the thinnest dusting of carbonate sediments on the mounds, in an area with among the highest biogenic carbonate sediment accumulate rates in the world $(\sim 50 \mathrm{~m} / \mathrm{m}$.y.; Klitgord and Mudie, 1974; Pisias, 1976). Prior to the Leg 54 drilling, surface samples of the mounds had been obtained by 


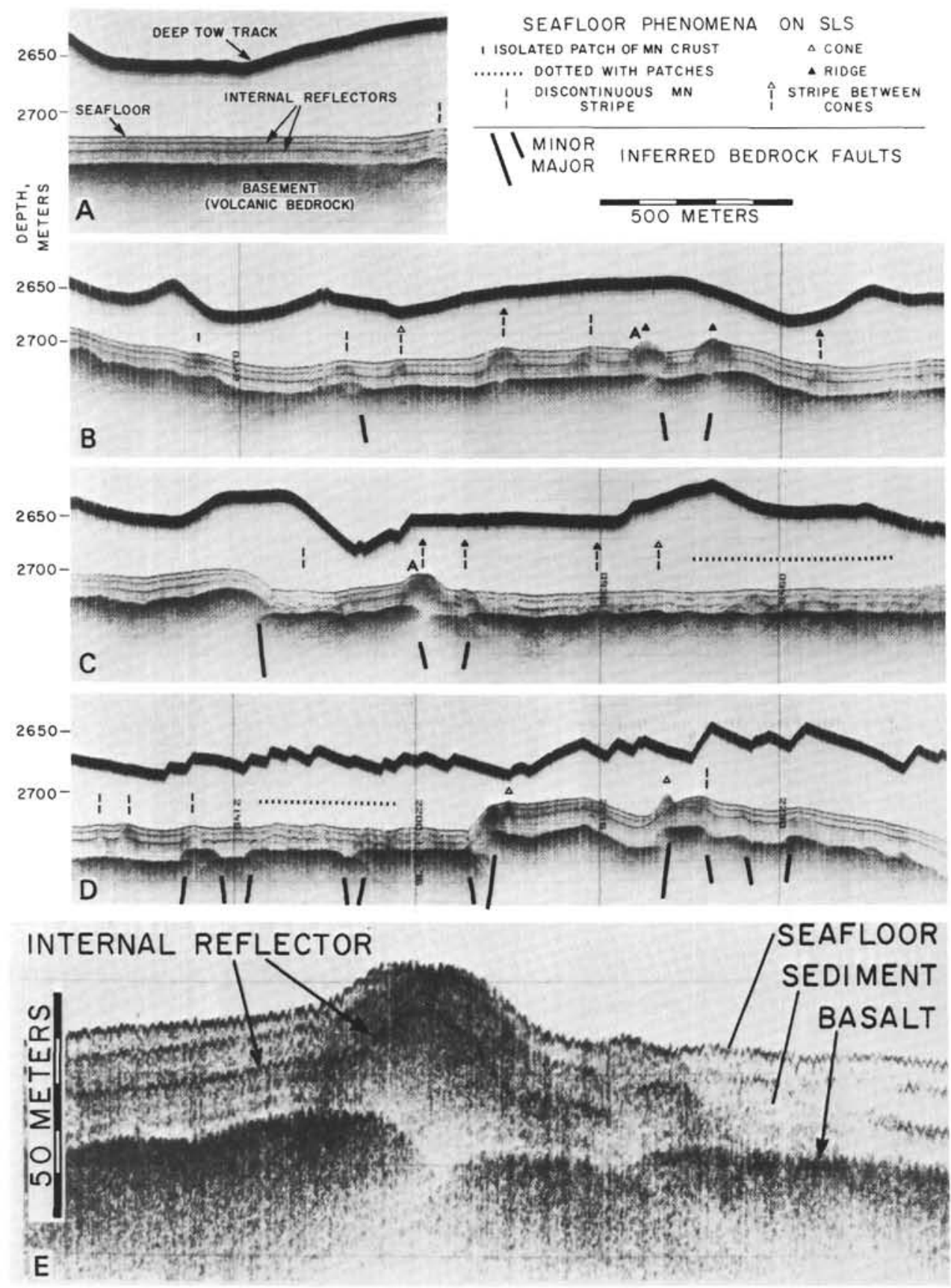

Figure 11. (A-D) near-bottom, 3.5-kHz profiles of the mounds geothermal field; (E) detail of mound from deep-tow 3.5-kHz records. (A-E) from Lonsdale (1977a) with permission. Note upward arching of reflectors toward mound. The reflectors appear locally discontinuous and at different depths on right side of record.

dredging (Corliss et al., 1978) and were found to consist primarily of dark Fe-Mn oxides, brown to yellow oxyhydroxides, and the smectite mineral nontronite. Similar samples were recovered by submersible (Corliss et al., 1979a) as well as hot water samples $\left(5-12^{\circ} \mathrm{C}\right)$ from the mounds. They were seen to support a thriving bottom community of clams and varieties of tube worms.

In our previous discussion, we had focused on hydrothermal sedimentary precipitates dispersed in biogenic pelagic sediments in small ponds more than $100 \mathrm{~km}$ west of the East Pacific Rise. The Galapagos Mounds geothermal field, however, is only $17-25 \mathrm{~km}$ south of the Galapagos Rift on crust about 600,000 years old (estimated from magnetic anomalies; Klitgord and Mudie, 1974), and is uniformly blanketed with about $25-30$ meters of sediments apart from the mounds. It is well south of the axial magma reservoir (Rosendahl and Dorman, this volume), and has variable heat flow, including some 
very high values, arranged in a pattern that is thought to characterize venting of heated, convectively circulating waters from the crust (e.g., Williams et al., 1974; Lister, 1972, 1974; Williams et al., 1979). It is such convective flow of water within basement that is the main agent of lithospheric cooling, shrinking, and subsidence near ridge crests (e.g., Sclater et al., 1971).

Drilling operations in the mounds area are described in the Galapagos Rift Site Report (this volume). Briefly, four holes were drilled; in three of them sediments were cored continuously (Figure 12). Two of these holes (Holes 424 and 424A) were targeted directly on mounds; one other is in a zone of flatter sediments with no evident basement faults between rows of mounds (Hole 424B). At the fourth hole, Hole $424 \mathrm{C}$, only a mudline core was taken in the sediments.

\section{MINERALOGY AND CHEMISTRY OF MOUNDS SEDIMENTS}

The hydrothermal deposits from Site 424 consist of two major types of material; a green, clay-rich fraction, and $\mathrm{Fe}-\mathrm{Mn}$ concretions which cap the mounds and which have been mixed by drilling with the clay-rich materials near the tops of the mounds. Green clays are especially abundant in Hole 424B where Mn oxides are absent, and in the lower portions of the two mounds holes, Holes 424 and 424A (Figure 13).

The green, clay-rich material is relatively soft and consists of irregular, semi-indurated chunks which are grayish olive, dark yellowish green, greenish black, and dusky brown. Under the microscope the individual grains are platey and have a very low birefringence. They are very friable, and have no apparent internal bedding. Separate chunks of this material are between 0.1 and $0.5 \mathrm{~cm}$ in diameter. In places these deposits appear to be entirely free of organic fragments or other pelagic materials. X-ray diffraction patterns of the green, clay-rich material show peaks at 11.5-12.0 $\AA$ which expand upon glycolation to $17 \AA$. The greener clays have peaks closer to $11 \AA$, whereas those having a dusky brown color are closer to $12 \AA$. These clays therefore are all trioctahedral smectite (Hoffert et al., this volume). Other minor constituents occur, such as amorphous silica, geothite ( $4.19 \AA$ peak), and a clay mineral with a basal $10 \AA$ peak, perhaps glauconite or celadonite.

Chemically the green, clay-rich material found in Holes 424, 424A, and 424B has uniformly high $\mathrm{Fe}$ (about $22 \%$ on average) and $\mathrm{Si}$ (up to $26 \%$ ), appreciable $\mathrm{Mg}$ (Table 2$)$ but low $\mathrm{Mn}(<1 \%)$ and $\mathrm{Al}(<1 \%)$ (Tables 3 and 4). $\mathrm{Fe}_{2} \mathrm{O}_{3} / \mathrm{FeO}$ is high, since there is typically less than 1 per cent $\mathrm{FeO}$ (Donnelly, this volume and Appendix; Rateev et al., this volume). Transition trace metal abundances are low (Table 4) with Ni averaging less than $20 \mathrm{ppm}, \mathrm{Cu}$ less than $40 \mathrm{ppm}$, and Co less than 30 $\mathrm{ppm}$. The green, clay-rich material of Hole 424B differs slightly from that in the other holes in having higher $\mathrm{Zn}$ (about $120 \mathrm{ppm}$ ) and $\mathrm{Cu}$ (about $100 \mathrm{ppm}$ ) contents (Table 4), and low rare-earth element abundances (Hoffert et al., this volume), with a distinctly low Ce content. This apparently reflects precipitation of the clay miner- als from sea water. The green, clay-rich material differs considerably from Cronan's (1972) average Pacific pelagic clay and manganese nodules (Table 3 ). In their general characteristics, the green, clay-rich deposits described here are similar to the clay-rich hydrothermal deposits found in transform fault " $\mathrm{A}$ " in the FAMOUS area (Hoffert et al., 1978) and in the Gulf of Aden (Cann et al., 1977). The $\mathrm{Ni}, \mathrm{Cu}$, and $\mathrm{Co}$ contents from all these deposits are less than $100 \mathrm{ppm}$ each, all less than half that in average pelagic clay.

The chemical variation among the different types of hydrothermal materials, and also between these and other types of deposits, can be visualized using a ternary diagram with apices $\mathrm{Fe}, \mathrm{Mn}$, and $\mathrm{Cu}+\mathrm{Ni}+\mathrm{Co}$ (Figure 14). The field of green, clay-rich material clusters near the Fe corner, whereas Pacific manganese nodules and the Fe-Mn encrustations of basaltic rocks are far more enriched in $\mathrm{Cu}+\mathrm{Ni}+\mathrm{Co}$ than any of the green, clay-rich deposits.

Donnelly (this volume) used bulk sediment analyses of the green, clay-rich materials to calculate structural formulae. He computed two types. The first was based on a hypothetical $\mathrm{A} 1$-free basis assuming all $\mathrm{Fe}$ as ferric:

$$
\left(\mathrm{K}_{0.71}\right)\left(\mathrm{Fe}_{2.86}^{3+} \mathrm{Mg}_{1.38}\right)\left(\mathrm{Si}_{7.94} \mathrm{Fe}_{0.06}^{3+}\right) 0_{20}(\mathrm{OH})_{4}
$$

The second formula was computed assuming end-member compositions, allotting $\mathrm{Na}$ and $\mathrm{Ca}$ to interlayered positions, and assigning all the A1 to tetrahedral positions:

$$
\begin{gathered}
\left(\mathrm{K}_{0.53} \mathrm{Na}_{0.18} \mathrm{Ca}_{0.21}\right)\left(\mathrm{Fe}_{3.01}^{3+} \mathrm{Mg}_{0.92} \mathrm{Al}_{0.08}\right) \\
\left(\mathrm{Si}_{7.71} \mathrm{Al}_{0.22} \mathrm{Fe}_{0.07}^{3+}\right) \mathrm{O}_{20}(\mathrm{OH})_{4}
\end{gathered}
$$

Both X-ray diffraction determinations and these structural formulae thus indicate that the green, clay-rich material consists essentially of nontronite and mixedlayer celandonite-nontronite.

Iron and manganese concretions are disseminated throughout the green, clay-rich material at the tops of Holes 424 and 424A (Figure 12). In Hole 424A, they mainly occur in discrete portions of Cores 1 and 2 . The FeMn concretions occur usually in individual chunks with irregular shapes (3-4 cm in diameter), often with a black or dark gray sub-metallic luster (Figure 13). Other, somewhat platey materials are earthy in appearance, and dark gray in color. These consist of two end components, Fe-Mn oxides, and clay minerals chemically equivalent to the green nontronites deeper in the holes (Schrader et al., this volume). Mineralogically, the FeMn oxides are mainly todorokite, with some birnessite (Schrader et al., this volume; Hoffert et al., this volume). The more pure $\mathrm{Fe}-\mathrm{Mn}$ oxides have botryoidal surface textures. One tabular fragment from Hole 424 (Section 1-1; Figure 13) has a conical shape resembling a small ice-cream cone; we presume it to have formed around the home of some organism.

Chemically, the $\mathrm{Fe}-\mathrm{Mn}$ concretions are rich in $\mathrm{Mn}$ (about $33 \%$ ), relatively poor in $\mathrm{Fe}(22 \%)$, and contain much lower concentrations of transition metals ( $\mathrm{Zn} 200$ ppm, Cu 50 ppm, Ni 100 ppm) than typical Pacific manganese nodules (Table 2; Figures 14, 15, and 16). In these 

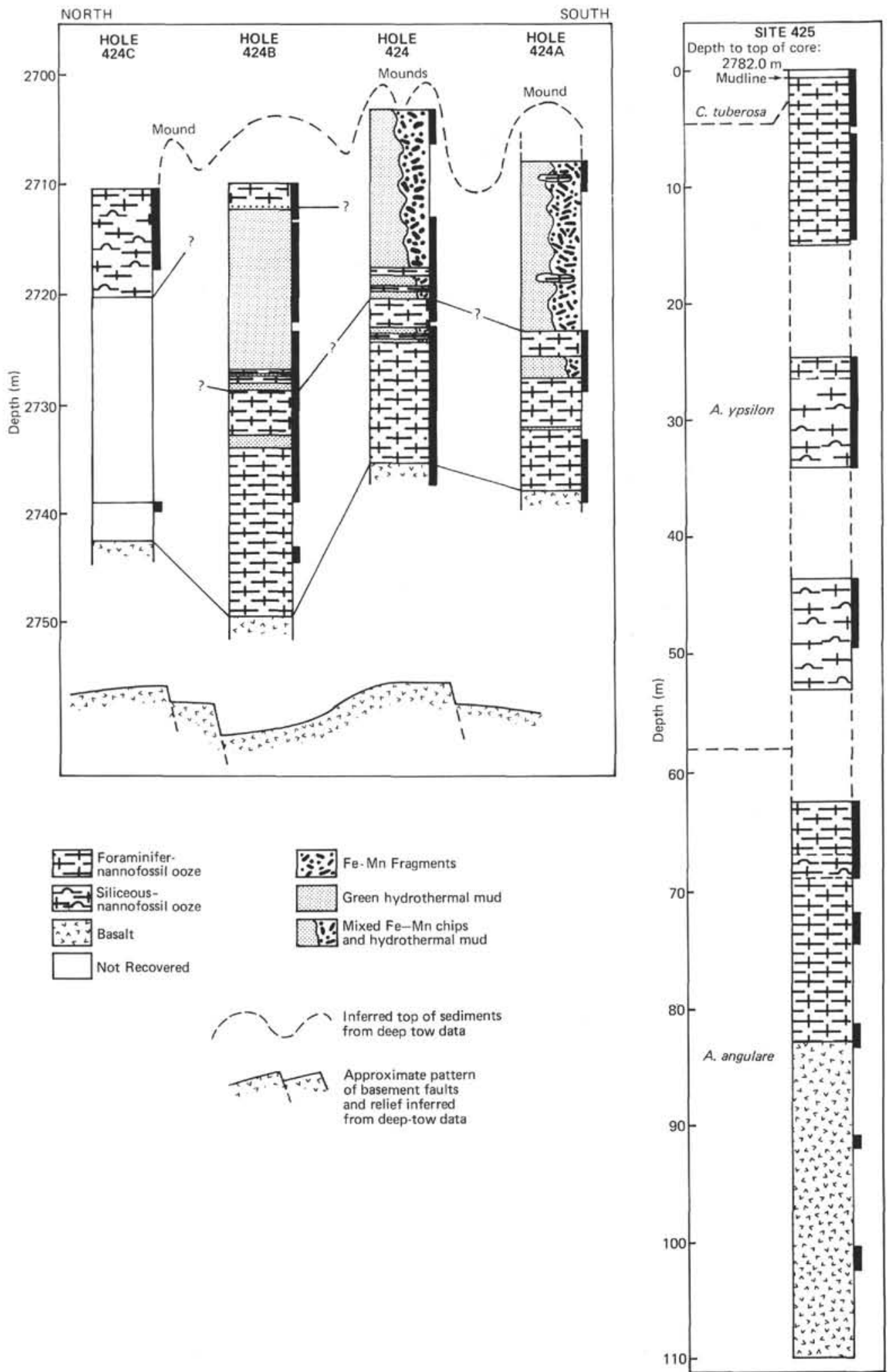

Figure 12. Lithologic columns for sediments of Sites 424 and 425 . Holes 424, 424A, $424 B$, and $424 C$ were drilled approximately 300 meters from each other on a northsouth line. Core recovery is indicated by black bars to right of columns (top of each bar is top of a core). Lines between columns indicate possible biostratigraphic correlations. Dashed line at top indicates inferred sediment surface based on deep-tow survey (Lonsdale, 1977a) and mudline core of Hole 424C. Stippled schematic basement profile below Site 424 columns is shown to indicate placement of basement faults. 

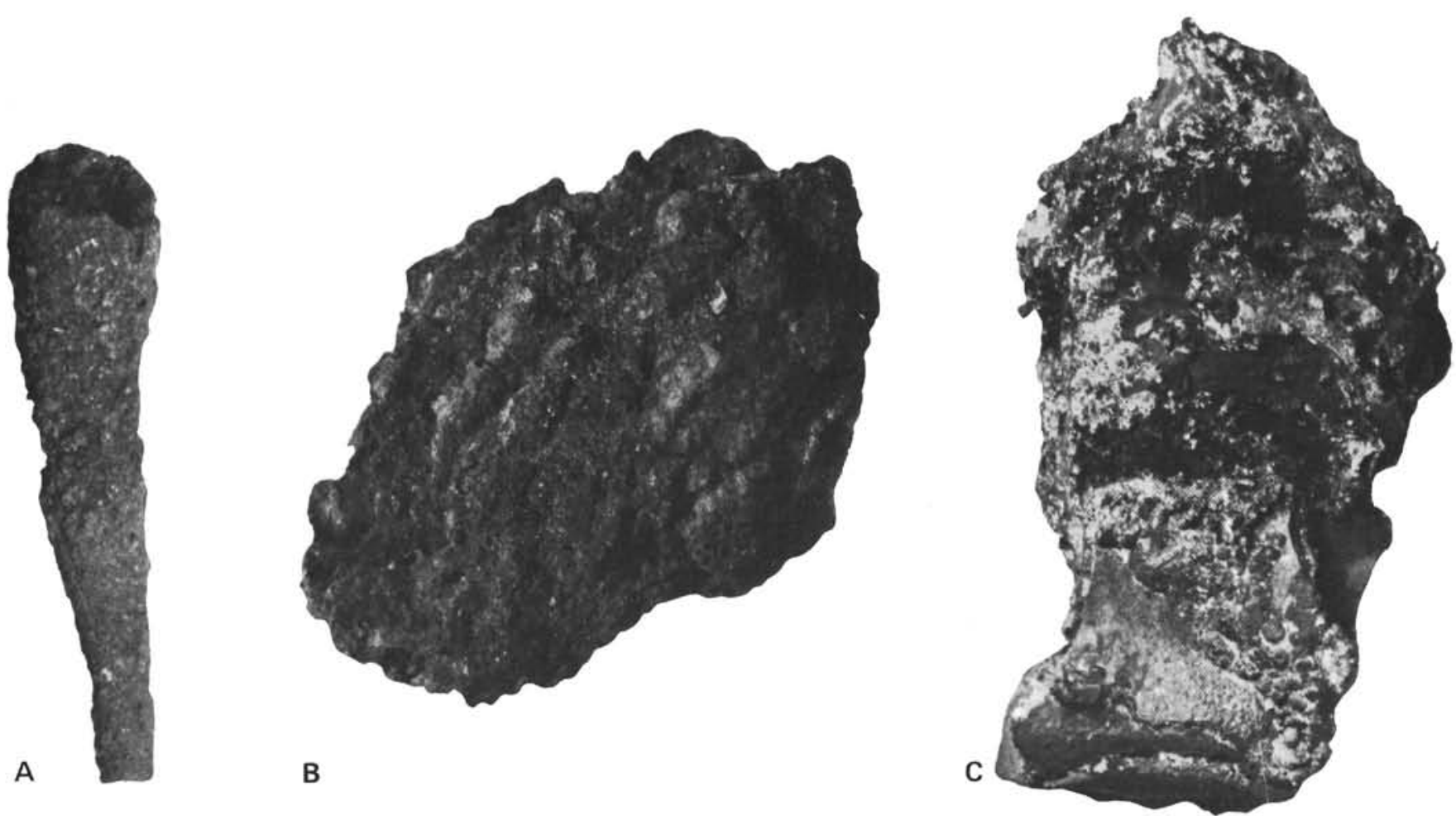

Figure 13. Photographs of hydrothermal materials at Site 424. (A) Tube of organism replaced by Fe-Mn material about $2.5 \mathrm{~cm}$ long; (B) Clump of green nontronitic material $(3.6 \mathrm{~cm}$ in length; (C) Chunk of $\mathrm{Fe}-\mathrm{Mn}$ concretion about $4.2 \mathrm{~cm}$ in length (Sample 424-3-4, 120-122 cm).

TABLE 3

Composition of Galapagos Hydrothermal Sediment From Holes 424 and $424 \mathrm{~A}$ with Other Sediment Types for Comparison

\begin{tabular}{|c|c|c|c|c|c|c|c|c|c|}
\hline & $\begin{array}{l}\mathrm{Fe} \\
(\%)\end{array}$ & $\begin{array}{l}\mathrm{Mn} \\
(\%)\end{array}$ & $\begin{array}{c}\mathrm{Ni} \\
(\mathrm{ppm})\end{array}$ & $\begin{array}{c}\mathrm{Co} \\
\text { (ppm) }\end{array}$ & $\begin{array}{c}\mathrm{Pb} \\
(\mathrm{ppm})\end{array}$ & $\underset{\text { (ppm) }}{\mathrm{Zn}}$ & $\begin{array}{c}\mathrm{Cu} \\
(\mathrm{ppm})\end{array}$ & $\begin{array}{c}\mathrm{Al} \\
(\%)\end{array}$ & $\begin{array}{l}\mathrm{Mg} \\
(\%)\end{array}$ \\
\hline 1 & 21.6 & 0.10 & 16 & 22 & 60 & 35 & 14 & 0.12 & 2.54 \\
\hline 2 & 5.06 & 0.48 & 211 & 101 & 68 & 165 & 323 & 8.4 & 2.1 \\
\hline 3 & 7.25 & 33.0 & 81 & 16 & 48 & 126 & 39 & 0.15 & 1.65 \\
\hline 4 & 11.96 & 19.78 & 6340 & 3350 & 846 & 680 & 3920 & 3.06 & 1.71 \\
\hline
\end{tabular}

Notes:

$1=$ Average values in 11 Galapagos green clays from Mounds Area (Hekinian et al., 1978).

2 = Average of Pacific pelagic clay (Cronan and Tooms, 1969; Turekian and Wedepohl, 1961).

$3=$ Ferromanganese concretions from Mounds Area (this work).

4 = Average of Pacific manganese nodules (Cronan, 1972).

*Analysis by atomic absorption spectrophotometry.

respects, the Fe-Mn concretions from the drilled holes are similar to hydrothermal deposits from the FAMOUS area (Hoffert et al., 1978), from the surfaces of other mounds in the Galapagos Mounds region (Corliss et al., 1978; Dymond et al., this volume), from the Gulf of Aden (Cann et al., 1977), and from the TAG area near $26^{\circ} \mathrm{N}$ on the Mid-Atlantic Ridge (M. R. Scott et al., 1974, 1979; R. B. Scott et al., 1972; Temple et al., 1979). They are also similar to thick Fe-Mn encrustations on basalts found on the Galapagos Spreading Center in and near its axial rift west of the Galapagos Islands (Moore and Vogt, 1976) and from the caldera region of a seamount near the crest of the East Pacific Rise in the Siqueiros region (Lonsdale et al., in press). These, however, have no associated A1-poor nontron- ites, and perhaps should be thought of as variants of the iron hydroxide facies already discussed, but in very concentrated form (e.g., Edmond et al., 1979c).

As mentioned earlier, the hydrothermal deposits of the mounds region lie within a pelagic sediment cover. Although interlaying between the nontronites and normal pelagic sediments occurs, the contacts are typically sharp. Some of the hydrothermal material, however, is intermixed with up to 10 per cent of pelagic sediments, especially in Hole 424, Core 3, Section 5; Hole 424A, Core 2, Section 3, and Hole 424B, Core 3, Section 5, and all of Core 4 . It is probable that much of this was caused by drilling disturbance, but some of it certainly occurred because of simultaneous deposition of biogenic and hydrothermal material. The pelagic sediment is made of foraminifer-nannofossil ooze containing about 15-20 per cent foraminifers, 55-70 per cent nannofossils, and about 15-20 per cent clay particles, mainly of a detrital nature. A siliceous nannofossil ooze is found only near the top of Hole $424 \mathrm{C}$ and consists of about 50-65 per cent nannofossils, $10-15$ per cent foraminifers, about 10 per cent clay, 5-20 per cent diatoms, and about 5 per cent sponge spicules.

This latter core does not contain any particular amount of hydrothermal material (Figure 12). X-ray diffraction patterns of the 2-micron fraction mixed with the pelagic sediments show a $15 \AA$ Å peak which corresponds to smectite. Since both illite and chlorite are associated with this smectite, it is probably detrital in origin. Dymond et al. (this volume) used a linear programming technique to 
TABLE 4

Chemical Analyses of Representative Samples from the Galapagos Spreading Center

\begin{tabular}{|c|c|c|c|c|c|c|c|}
\hline \multirow{2}{*}{$\begin{array}{l}\text { Oxides } \\
\text { (wt. \%) }\end{array}$} & \multicolumn{5}{|c|}{ Greey Clay-Rich Material } & \multirow{2}{*}{$\begin{array}{c}\begin{array}{c}\text { Foraminifer- } \\
\text { Nannofossil } \\
\text { Ooze }\end{array} \\
424-4-6 \\
39-41 \\
\end{array}$} & \multirow{2}{*}{$\begin{array}{c}\text { Fe-Mn } \\
\text { Concretion } \\
424-3-5, \\
35-40 \\
\end{array}$} \\
\hline & $\begin{array}{c}424-1-1 \\
90\end{array}$ & $\begin{array}{c}424-2-2 \\
11-13 \\
\end{array}$ & $\begin{array}{c}424-2-4 \\
30-33\end{array}$ & $\begin{array}{c}424 \mathrm{~A}-2-2 \\
9-11\end{array}$ & $\begin{array}{c}424 \mathrm{~B}-2-2 \\
50-52\end{array}$ & & \\
\hline $\begin{array}{l}\mathrm{SiO}_{2} \\
\mathrm{Al}_{2} \mathrm{O}_{3} \\
\mathrm{Fe}_{2} \mathrm{O}_{3} \\
\mathrm{MnO} \\
\mathrm{MgO} \\
\mathrm{CaO} \\
\mathrm{Na}_{2} \mathrm{O} \\
\mathrm{K}_{2} \mathrm{O} \\
\mathrm{TiO}_{2} \\
\mathrm{Ign} .\end{array}$ & $\begin{array}{r}49.35 \\
0.52 \\
30.38 \\
0.14 \\
2.37 \\
0.05 \\
- \\
2.27 \\
0.03 \\
13.9\end{array}$ & $\begin{array}{c}53.3 \\
0.20 \\
30.6 \\
0.17 \\
4.41 \\
0.30 \\
2.08 \\
3.39 \\
0.02 \\
6.79\end{array}$ & $\begin{array}{r}45.95 \\
0.32 \\
28.12 \\
0.06 \\
3.71 \\
0.17 \\
1.43 \\
3.65 \\
0.02 \\
15.84\end{array}$ & $\begin{array}{c}51.4 \\
0.2 \\
29.0 \\
0.12 \\
4.43 \\
0.6 \\
2.2 \\
3.91 \\
0.02 \\
6.81\end{array}$ & $\begin{array}{c}53.9 \\
0.50 \\
29.5 \\
0.06 \\
3.60 \\
0.40 \\
2.47 \\
2.96 \\
0.04 \\
6.37\end{array}$ & $\begin{array}{c}12.3 \\
2.60 \\
2.2 \\
1.03 \\
1.73 \\
41.5 \\
0.06 \\
0.05 \\
0.10 \\
36.00\end{array}$ & $\begin{array}{r}0.71 \\
0.78 \\
0.34 \\
70.89 \\
3.19 \\
1.37 \\
- \\
0.28 \\
\overline{23.15}\end{array}$ \\
\hline Total & 99.01 & 100.26 & 99.27 & 98.81 & 99.80 & 99.41 & 100.71 \\
\hline $\begin{array}{l}\mathrm{Fe}(w t . \%) \\
\mathrm{Mn}(w t . \%)\end{array}$ & $\begin{array}{r}21.27 \\
0.11\end{array}$ & $\begin{array}{r}21.42 \\
0.13\end{array}$ & $\begin{array}{r}21.89 \\
0.05\end{array}$ & $\begin{array}{r}20.30 \\
0.09\end{array}$ & $\begin{array}{r}20.65 \\
0.05\end{array}$ & $\begin{array}{l}1.54 \\
0.96\end{array}$ & $\begin{array}{r}0.24 \\
54.90\end{array}$ \\
\hline \multicolumn{8}{|l|}{ Trace Elements } \\
\hline $\begin{array}{l}\mathrm{Co}(\mathrm{ppm}) \\
\mathrm{Cu}(\mathrm{ppm}) \\
\mathrm{Zn}(\mathrm{ppm}) \\
\mathrm{Ni}(\mathrm{ppm}) \\
\mathrm{Pb}(\mathrm{ppm}) \\
\mathrm{Cr}(\mathrm{ppm})\end{array}$ & $\begin{array}{l}- \\
- \\
- \\
-\end{array}$ & $\begin{array}{r}3 \\
30 \\
53 \\
10 \\
55 \\
9\end{array}$ & $\begin{array}{l}- \\
- \\
- \\
- \\
-\end{array}$ & $\begin{array}{r}15 \\
61 \\
108 \\
34 \\
23 \\
10\end{array}$ & $\begin{array}{r}3 \\
100 \\
118 \\
16 \\
62 \\
13\end{array}$ & $\begin{array}{r}2 \\
32 \\
45 \\
55 \\
10 \\
15\end{array}$ & $\begin{array}{l}- \\
- \\
- \\
-\end{array}$ \\
\hline
\end{tabular}

Notes: Samples 424-1-1, $90 \mathrm{~cm} ; 424-2-4,30-35 \mathrm{~cm}$; and 424-3-5, 35-40 cm were analyzed by X-ray fluorescence (Cambon and Etoubleau, analysts, COB). Samples 424-2-2, 11-13 cm;424-4-6, 39-41 cm, 424B$2-2,50-52 \mathrm{~cm}$; and $424 \mathrm{~A}-2-2,9-11 \mathrm{~cm}$, were analyzed by arc spectrometry (Université de Strasbourg). Ign. indicates ignition loss at $1000^{\circ} \mathrm{C}$ (Hoffert et al., this volume).

establish the mineralogical composition of Site 424 sediments by calculating bulk compositions into various end members (i.e., nontronite, biogenic carbonate, hydrogenous manganese oxides, biogenic opal, hydrothermal birnessite-todorokite, detrital silicates, and barite). They found that basal pelagic oozes in Holes 424 and $424 \mathrm{~B}$, in particular, have virtually no nontronite component, but between 11 and 14 per cent detrital silicates, which must be mainly clays. Dymond et al. (this volume) also found them to contain a small "oxalate-soluble" iron hydroxide component which probably was added to the basal sediments at the Galapagos Rift axis.

\section{HYPOTHESES ON THE ORIGIN OF THE MOUNDS}

The Leg 54 scientific party has advanced three hypotheses on the origin of the mounds. The first two stem from a close similarity of the mounds deposits to those adjacent to small vents in fracture zone "A" in the FAMOUS area in the North Atlantic (see Figures 15 and 16) as described by Hoffert et al. (1978). The two hypotheses, cited in Hekinian et al. (1978) are (1) that the hydrothermal sediments form within the sediment blanket as precipitates from fluxes venting from basement, and (2) that the precipitates form by reaction between sea water and fluxes on the sea floor, with the bedded nature of the deposits resulting from alternations of hydrothermal discharge and intervals of pelagic sediment deposition. In both of these hypotheses, mounds were viewed as local phenomena, forming strictly above source vents. In both cases, the separation of $\mathrm{Mn}$ from
Fe was ascribed to the fractional precipitation of iron following a mixing of hydrothermal solutions with sea water (Krauskopf, 1957).

The third hypothesis attempted to integrate the mounds stratigraphy and the acoustic stratigraphy of the region into a unified explanation for the distribution and origin of the hydrothermal sediments (Natland et al., 1979). Several features of the stratigraphy implied a possible widespread distribution of the green muds:

1) The basal carbonate later is about the same thickness in Holes 424, 424A, and 424B (Figure 12).

2) The top and bottom of the green mud layer in Hole 424B, which was deliberately cored for an offmounds reference section of the local sediment blanket, approximate the depths of two reflectors charted with the deep-tow $3.5-\mathrm{kHz}$ system (see Galapagos Site Report, this volume, for details).

3) We recovered no ash layers, hypothesized by Lonsdale (1977a) to account for the reflectors.

4) The top of the basal carbonate layer in all three holes was deposited about 300,000 years ago (assuming a normal depositional sequence rather than an injection or replacement phenomenon), based on uniform sedimentation rates.

5) This age matches that of basement inferred from uniform spreading rates (Klitgord and Mudie, 1974), where the deeper of the two reflectors pinches out on basement some $7 \mathrm{~km}$ to the north.

6) The green muds in Hole 424B are compositionally very pure and uniform from top to bottom (Hoffert et al., this volume; Natland et al., 1979), are the same 


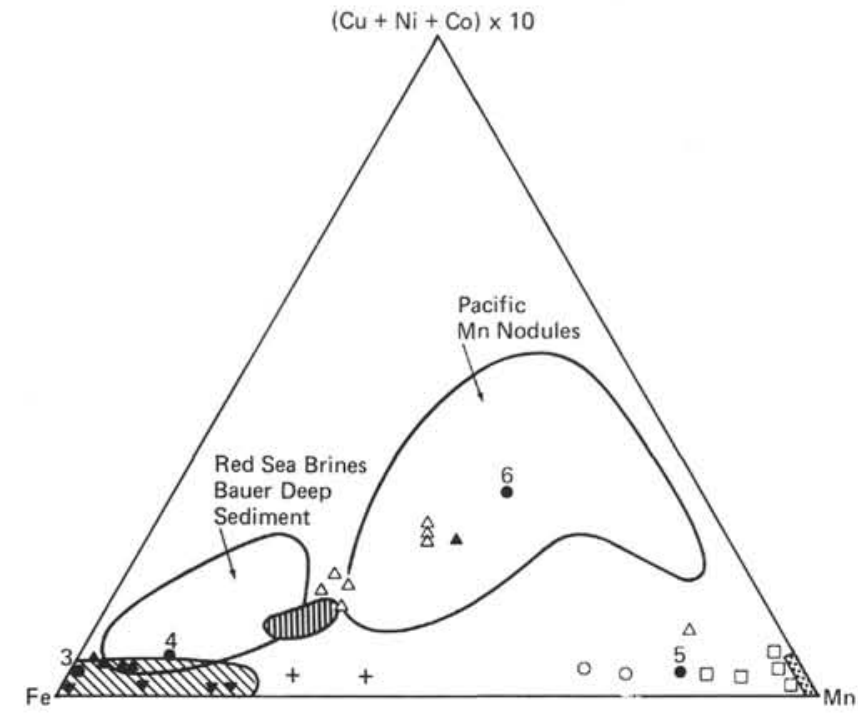

Figure 14. $(\mathrm{Cu}+\mathrm{Ni}+\mathrm{Co}) \mathrm{I0}-\mathrm{Fe}-\mathrm{Mn}$ ternary diagram showing the field of Pacific manganese nodules, metalliferous sediments from the Red Sea (Bischoff, 1969) and Bauer Deep (Sayles and Bischoff, 1973), and hydrothermal deposits from the Antarctic, Pacific, and Indian oceans (Hoffert et al., 1978; R. B. Scott et al., 1972; M. R. Scott et al., 1974; Cann et al., 1977). (3) is average of 11 green nontronitic sediments from Site 424. (5) is average of composite $\mathrm{Fe}-\mathrm{Mn}$ concretions from Site 424. (6) is average of Pacific Fe-Mn nodules (Cronan, 1972); (4) is average of Pacific pelagic clay (Cronan, 1972). (O) is $\mathrm{Fe}-\mathrm{Mn}$ concretions from transform fault " $A$ " in the $F A$ MOUS area (Hoffert et al., 1978). The diagonally striped field is green nontronitic deposits from transform fault " $A$." The vertically striped field is $\mathrm{Fe}-\mathrm{Mn}$ coatings of basaltic rock from the FAMOUS area. Open squares are $\mathrm{Fe}-\mathrm{Mn}$ concretions from the Gulf of Aden (Cann et al., 1977). (+) is green clay and a mix of Fe-Mn oxides from the Gulf of Aden (Cann et al., 1977). (ם) is nontronite and Fe oxide coatings from the Galapagos Rift (Corliss et al., 1978). $(\triangle)$ is $\mathrm{Fe}-\mathrm{Mn}$ coatings from a Pacific seamount (Bonatti and Joensuu, 1966). ( $\mathbf{\Delta}$ ) is $\mathrm{Fe}-\mathrm{Mn}$ coatings from the TAG area in the North Atlantic (M. R. Scott et al., 1974).

composition as green muds in the other two holes, and in Hole 424B lack a capping of Mn oxides (Figure 17).

7) There are several small, flat-lying interbeds of green mud below the principal thick beds of hydrothermal material in all the holes (Figure 12).

Natland et al. (1979) consequently proposed that there is a widespread green mud layer underlying the sea floor in the region, and that the mounds themselves are more recent and restricted manifestations of a once much wider field of hydrothermal precipitates. Originally, the mounds deposits were proposed to be almost exclusively iron smectites. Now they are both iron smectites and Mn oxides. These changes were proposed to reflect changes in the underlying crustal hydrothermal system itself, shifting from rock-dominated basalt/sea wa-

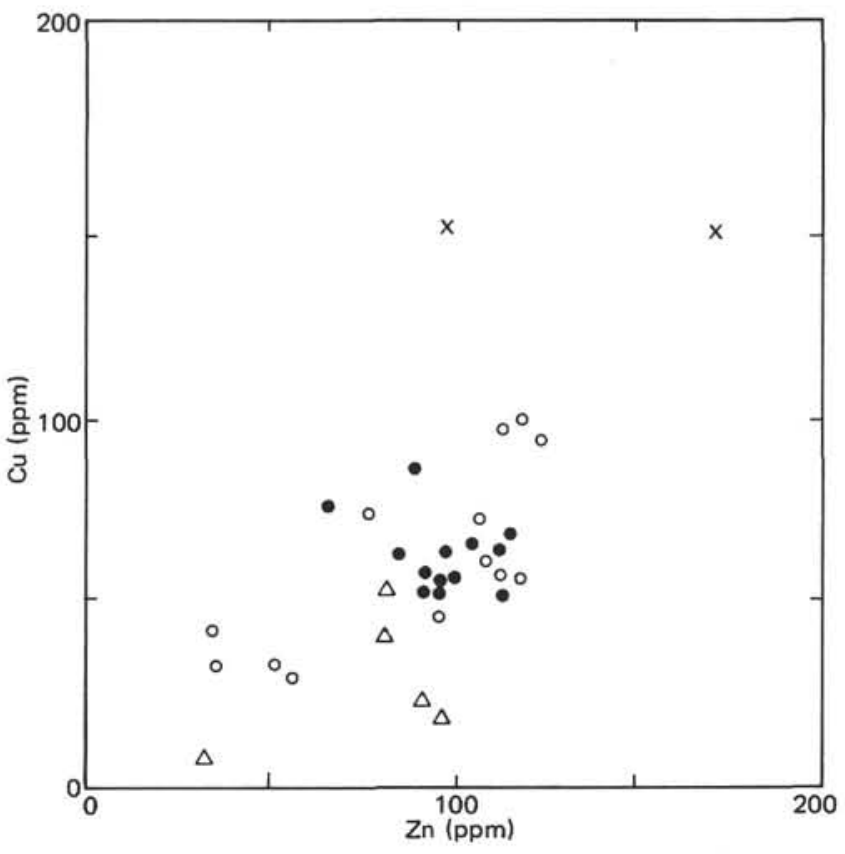

Figure 15. Cu-Zn variation diagram of green nontronitic materials $(\mathrm{O}), \mathrm{Fe}-\mathrm{Mn}$ concretions $(X)$, pelagic sediments $(\triangle)$, and basement rocks ( $\bullet$ ) from Holes $424,424 A, 424 B$, and $424 C$. Sediment and $\mathrm{Fe}-\mathrm{Mn}$ concretion data from Hoffert et al. (this volume). Basalt data from Mattey and Muir (this volume) and Srivastava et al. (this volume).

ter interactions, to water-dominated interactions through time. The sequence of precipitates was compared to sea water/basalt experiments which showed a higher proportion of solubilized metals in water-dominated than in rock-dominated systems (Seyfried and Bischoff, 1977).

We emplasize that we did not core into basement vents actively fluxing hydrothermal fluids, nor did we recover hydrothermally modified sediments just above basement. Either basement vents are very narrow, and we missed them, or there is no necessarily direct pathway from basement vents to the mounds. Natland et al. (1979) suggested that the mounds could form simply along structural discontinuities in basement which introduce lines of weakness in the incompetent sediment layer. This would be possible with a widespread green mud layer. Without such a layer, the mounds would in some way have to lie directly over source vents, for which we had no evidence.

Variations of the two hypotheses presented in Hekinian et al. (1978) have been proposed independently by others. Williams et al. (1979) argue that the nontronites may form internally by dissolution of carbonate and transformation of biogenic opal to nontronite as it interacts with $\mathrm{Fe}$ - and $\mathrm{Si}$-bearing hydrothermal solutions. They see the mounds as features which expand internally as precipitates are added from underneath. The Mn oxides capping the mounds precipitate as the hydrothermal fluids react with oxygenated sea water. These cappings do not become excessively thick because the Mn 


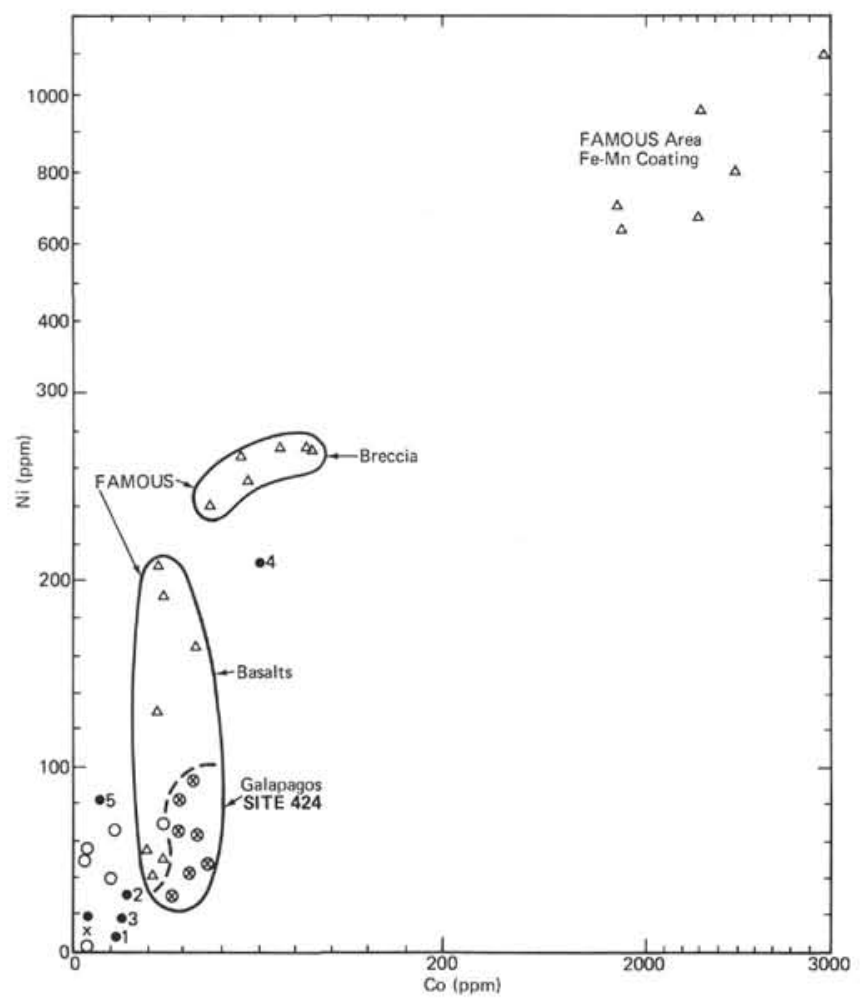

Figure 16. Ni-Co variation diagram of hydrothermal material and associated basaltic rocks from the $\mathrm{Ga}$ lapagos Rift and the FAMOUS area $\left(37^{\circ} \mathrm{N}\right.$, MidAtlantic Ridge). (O) green nontronitic material from Site 424; (1) is the maximum value of $\mathrm{Ni} / \mathrm{Co}$ obtained from analysis of green nontronitic material (Table 2); (2) is the minimum value; (3) is the average value; (4) is average Pacific pelagic clay (Table 2); (5) composite $\mathrm{Fe}-\mathrm{Mn}$ concretions from Site 424. Basalt data for Site 424 from Mattey and Muir (this volume) and for FAMOUS area from Hekinian et al. (1976). FAMOUS area "breccias" include fragments of olivinerich basalts set in a ferruginous matrix (analyses by quantometry; C.R.P.G., Nancy, France). The FAMOUS area $\mathrm{Fe}-\mathrm{Mn}$ coatings were scraped from the rock surfaces.

on the inside of cappings can redissolve, leaving the $\mathrm{Fe}$ to react with $\mathrm{Si}$ to form nontronite. Williams et al. (1979) imply that here should be a zone of diagenetically altered siliceous-carbonate ooze beneath mounds, even though we found no evidence for this in our cores.

Dymond et al. (this volume) find aspects of the nontronite layer hypothesis and the carbonate-opal dissolution hypothesis attractive. However, they question the former on the grounds that it apparently requires direct precipitation from hydrothermal solutions on the sea floor under at least mildly oxidizing conditions, and that it requires some sort of a ponding mechanism, similar to that in the Red Sea (e.g., Bischoff, 1969). This is difficult to envision in an open area of sea floor with low relief covering at least $380 \mathrm{~km}^{2}$ (Williams et al., 1979). They question the dissolution hypothesis on the grounds that the pelagic sediments cannot supply all of the $\mathrm{Si}$ and $\mathrm{Fe}$ in the green muds, and that the proposed transformation does not explain loss of most of the $\mathrm{Al}$, $\mathrm{Sc}, \mathrm{La}, \mathrm{Co}$, and $\mathrm{Ba}$ originally present in the pelagic sediments. These elements are particularly immobile in the sedimentary environment. Instead of either of these hypotheses, Dymond et al. (this volume) favor addition of hydrothermal precipitates to the sediment column at each mound, under the influence of a pronounced oxidation gradient at the sediment-water interface. This fractionates $\mathrm{Mn}$ from $\mathrm{Fe}$ in the manner suggested in $\mathrm{He}$ kinian et al. (1978). The major difficulty they see with this hypothesis is that half or more of the entire sediment column at each mound must be either displaced or replaced by mainly nontronites. While some of this may be explained by sediment redistribution (local variations in sedimentation rate), this cannot be a wholly satisfactory solution, and some form of sediment dissolution may need to occur, despite their criticisms of this hypothesis.

The recent drilling on the Galapagos Mounds during Leg 70 confirmed some, but not the most important, of the stratigraphic relationships inferred by Natland et al. (1979). Using the hydraulic piston corer, and recovering virtually undisturbed sediments, the green muds were indeed found to be interlayered with pelagic sediments. A basal carbonate layer several meters thick was found to underlie all three mounds cored, but the regional sediment blanket was found to be entirely pelagic in composition (Honnorez, Von Herzen, et al., in press). The green muds in Hole 424B must be, as suggested by Williams et al. (1979) and Dymond et al. (this volume), part of a buried mound. Some other cause for the reflectors must exist. Possibly, as suggested by Williams et al. (1979) they "represent the normal banding of equatorial pelagic calcareous deposits that is due to changes in carbonate dissolution (Berger and Mayer, 1978)."

Although this development entails that the mounds indeed are localized above basement vents on fault scarps, only detailed studies of the undisturbed piston cores and associated pore fluids will eliminate other important aspects of the hypothesis presented in Natland et al. (1979). It is most important to decide whether the green mud interbeds formed as deposits on the sea floor, were injected into the carbonate sediment blanket laterally, or formed by dissolution and replacement of pelagic sediments. If they were formed as deposits on the sea floor, then the question of why each interbed, and the buried mound at Hole 424B, are not associated with manganese oxides becomes important. Based on the experiments of Seyfried and Bischoff (1977), we do not believe that manganese need necessarily have been an abundant dissolved constituent in the hydrothermal fluids during the earlier history of the mounds field. Consequently, we hold it to be possible that green muds only were deposited next to source vents until quite recently. This hypothesis does not require large-scale ponding of brines to produce pure green muds, since they would still be localized around basement source vents. The possibility that the stratigraphic sequence in 

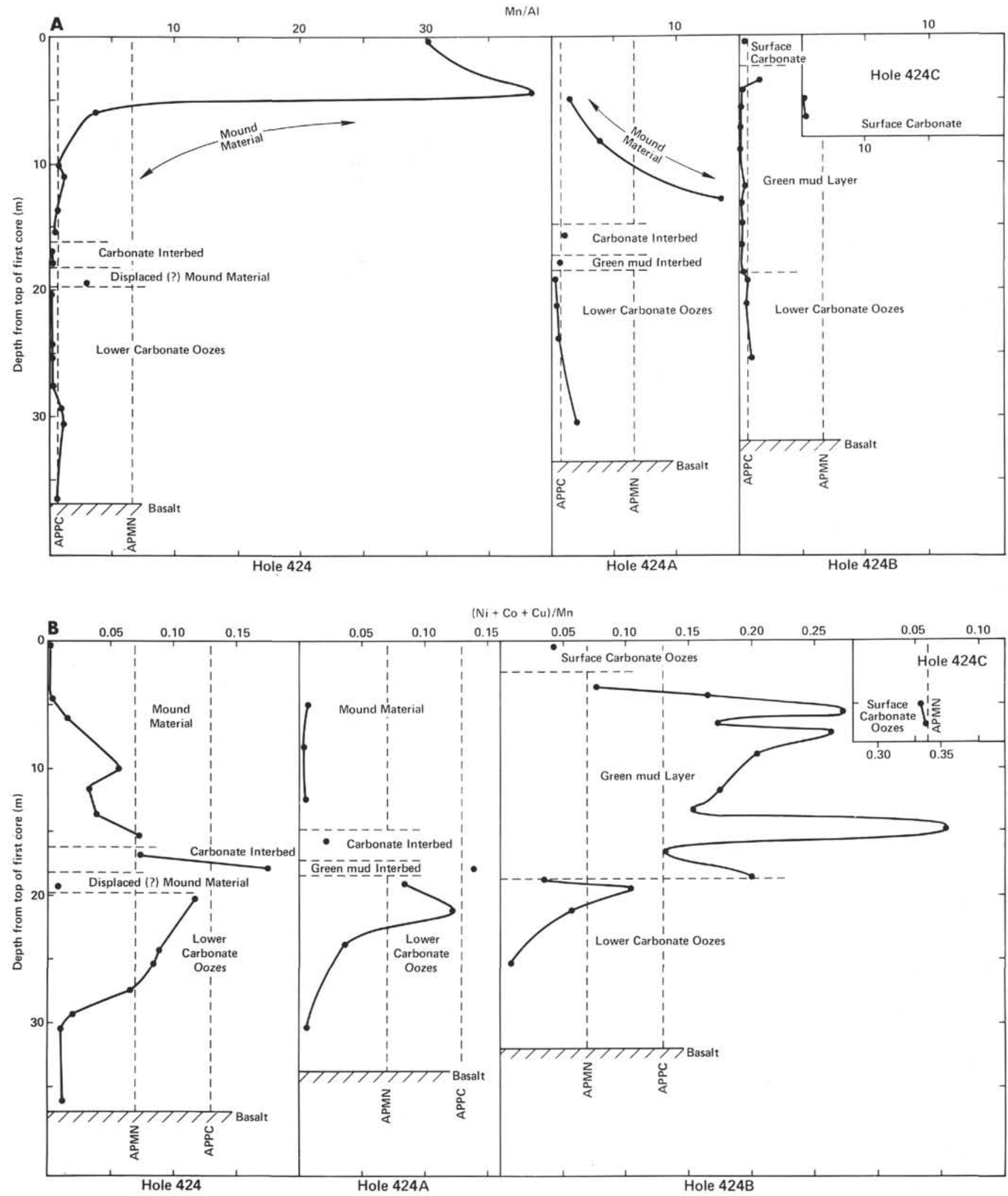

Figure 17. Plots of $(A) M n / A l$ and $(B)(N i+C o+C u) / M n$ against depth for Holes $424,424 A, 424 B$, and $424 C$. Data are from Hoffert et al. (this volume). Depth intervals were assigned by assuming that core recovery is representative of the entire 9.5-meter interval of each core. Abbreviations: APPC, average Pacific pelagic clay (Cronan, 1969) and APMN, average Pacific manganese nodules (Cronan, 1972). Reproduced from Natland et al. (1979) with permission. 
the mounds reflects a fundamental change in the composition of geothermal fluids exiting basement should still be explored.

We are skeptical that dissolution and diagenetic reaction between hydrothermal fluids and siliceous tests of micro-organisms (Williams et al., 1979) is an important process in producing the meters of nontronites cored. In addition to the objections of Dymond et al. (this volume) to dissolution, we again emphasize that the nontronites are quite pure, and have a very uniform composition (Figure 17; Tables 2 and 3; see Hoffert et al., this volume). Although the facies is not similar, the diagenetic reaction of iron hydroxides and siliceous microfossil tests at Site 420 on the East Pacific Rise, described earlier, has produced no such uniform nontronite compositions (e.g., Rateev et al., this volume). Moreover, green nontronites virually identical to mounds nontronites have been found encrusting basalts in the Gulf of Aden (Cann et al., 1977) and as beds 10 to $100 \mathrm{~cm}$ thick atop several meters of carbonate sediment adjacent to fissures into basement, which are presumed to be source vents, in fracture zone "A" in the FAMOUS area at $37^{\circ} \mathrm{N}$ in the Atlantic (Hoffert et al., 1978). In these two studies, the green nontronites are inferred to be direct precipitates from hydrothermal solutions, not the product of diagenetic reactions between hydrothermal fluids and sediments. This is our interpretation of the Galapagos Mounds deposits. The Gulf of Aden and fracture zone "A" deposits are also sufficient proof that a thin skin of sediments is not required to produce the oxidation gradients thought by Williams et al. (1979) to be necessary for fractionation of $\mathrm{Fe}$ from $\mathrm{Mn}$. Apparently, simple mixing of hydrothermal fluids with bottom waters can produce zoned deposits (Hoffert et al., 1978).

\section{ALTERATION OF BASALTS AT SITE 424}

Basalts at Site 424 are remarkably fresh even though they supposedly lie in the pathways of warm fluids discharging from the crust. The lack of alteration minerals is surprising considering that these fluids presumably are laden with dissolved constituents that precipitate mounds materials only a few meters above. Humphris et al. (Alteration chapter, this volume) describe the same type of alteration rinds at this site as in the East Pacific Rise sites and find no evidence whatsoever for high-temperature $\left(>120^{\circ} \mathrm{C}\right)$ alteration. Some traces of green clays with compositions similar to the green muds (Table 5) fill rare vesicles and line some microfractures. Traces of secondary sulfides occur in basalts of Hole 424. Presumably this alteration could have occurred by the action of fluids little warmer $\left(10^{\circ}-50^{\circ} \mathrm{C}\right)$ than those sampled from the mounds.

\section{ORIGIN OF MARINE SEDIMENTARY HYDROTHERMAL DEPOSITS}

We propose that there are two fundamental marine sedimentary hydrothermal facies: one produced at high temperatures generally above magma chambers of fast and intermediate spreading rises, the second, as a result
TABLE 5

Microprobe Analyses of Secondary Clay Material Found in Vesicles and in the Groundmass as Interstitial Products of Basement Rocks Associated with the Hydrothermal Deposits

\begin{tabular}{|c|c|c|c|c|}
\hline $\begin{array}{c}\text { Sample } \\
\text { (Interval in cm) }\end{array}$ & \multicolumn{2}{|c|}{$\begin{array}{l}424-5-1,38-40 \\
\text { (Piece 5) }\end{array}$} & \multicolumn{2}{|c|}{$\begin{array}{c}\text { 424B-6-1, 36-39 } \\
\text { (Piece 6) }\end{array}$} \\
\hline Color & $\begin{array}{c}\text { Modera } \\
\text { ish } \\
(10 \\
\end{array}$ & $\begin{array}{l}\text { te yellow- } \\
\text { orown } \\
\text { (R 5/4) }\end{array}$ & \multicolumn{2}{|c|}{$\begin{array}{c}\text { Light olive } \\
(10 \text { GY } 5 / 4) \\
\end{array}$} \\
\hline Lab No. & 24 & $\begin{array}{c}\text { Average of } 2 \\
25,26\end{array}$ & 1 & $\begin{array}{c}\text { Average of } 2 \\
4,5\end{array}$ \\
\hline $\mathrm{SiO}_{2}$ & 53.6 & 52.6 & 45.7 & 46.8 \\
\hline $\mathrm{Al}_{2} \mathrm{O}_{3}$ & 2.2 & 2.1 & 4.8 & 5.2 \\
\hline $\mathrm{FeO}$ & 13.3 & 13.4 & 25.7 & 27.6 \\
\hline $\mathrm{MgO}$ & 19.6 & 19.3 & 4.6 & 4.1 \\
\hline $\mathrm{MnO}$ & $<0.5$ & 0.00 & $<0.5$ & $<0.5$ \\
\hline $\mathrm{CaO}$ & 0.6 & $<0.5$ & 0.6 & 0.6 \\
\hline $\mathrm{Na}_{2} \mathrm{O}$ & 0.5 & $<0.5$ & $<0.5$ & $<0.5$ \\
\hline $\mathrm{K}_{2} \mathrm{O}$ & $<0.5$ & $<0.5$ & 6.4 & 5.3 \\
\hline $\mathrm{P}_{2} \mathrm{O}_{5}$ & 0.00 & 0.00 & $<0.5$ & 0.00 \\
\hline
\end{tabular}

Notes: $\mathrm{Ti}$ was not detected and the total $\mathrm{Fe}$ was calculated as $\mathrm{FeO}$. The colors are compared to Munsell rock-color charts.

of circulation of hydrothermal fluids to deep levels (3-5 $\mathrm{km}$ ?) in consolidated but still hot oceanic crust on the flanks of rises and ridges. We relate the hydrothermal component in our East Pacific Rise sediments to the first, and consider the Galapagos Mounds deposits to be type examples of the second. We shall consider each of these in turn.

\section{The Iron Hydroxide Facies}

A great variety of near-bottom observations, samples, and laboratory experiments allow us to state with a fair degree of certainty that the iron hydroxide facies so abundant on the East Pacific Rise originates upon expulsion of high-temperature hydrothermal fluids from source vents at the axes of the East Pacific Rise and the Galapagos Rift. Early studies had shown that the ironand manganese-hydroxide facies is concentrated near the Rise crest (e.g., Boström and Peterson, 1966; Boström et al., 1969; Dymond et al., 1973., Sayles and Bischoff, 1973; Heath and Dymond, 1977), but did not document the conditions of its formation. More recently, however, exhalations of $\mathrm{Fe}$ - and $\mathrm{Mn}$-rich solutions have been sampled over both the Galapagos Rift (Weiss et al., 1977; Corliss et al., 1979a; Edmond et al., 1979b) and the East Pacific Rise at $21^{\circ} \mathrm{N}$ (Lupton et al., 1979; Macdougall et al., 1979; Haymon et al., 1979). At the Galapagos Rift, they apparently contribute to a fine dusting of orange-brown sediment on adjacent bare basalts (Crane, 1978; Lonsdale, 1977b). A manganiferous component of this type apparently occurs in basal siliceous carbonate oozes in all three holes at Site 424 (Natland et al., 1979). Evidence for this is that the ratio $\mathrm{Mn} / \mathrm{Al}$ abruptly increases just above basalt, whereas the ratio $(\mathrm{Ni}+\mathrm{Co}+\mathrm{Cu}) / \mathrm{Mn}$ decreases (Figure 17). By the criteria discussed earlier, this Mn enrichment therefore is not hydrogenous, and consequently must be hydrothermal in origin. In addition, "oxalate-soluble" iron (occuring in hydroxide rather than clay-mineral form) is 
present just above basalts in the same three holes (Dymond et al., this volume). We infer these to be independent evidence for a basal non-hydrogenous Fe-Mn hydroxide component produced at the Galapagos Rift.

Besides manganese and iron, other species identified in waters venting from axial basement fissures at $21^{\circ} \mathrm{N}$ on the East Pacific Rise and at the Galapagos Rift include helium, silicon, barium, methane, hydrogen, nitrous oxide, carbon monoxide, chloride, and sulfate (Lilly and Gordon, 1979; Welhan and Craig, 1979; Lupton et al., 1979; McDuff and Edmond, 1979; Edmond et al., 1979a,b). Some of these appear to be juvenile components which are extracted into hydrothermal solutions. Evidence for this lies in the "primordial" mantle ${ }^{3} \mathrm{He} /{ }^{4} \mathrm{He}$ ratios of hydrothermal fluids mixed with sea water sampled at the Galapagos Rift (Lupton et al., 1977; Jenkins et al., 1978) and the East Pacific Rise (Lupton et al., 1979).

At the Galapagos Rift, the temperatures of waters sampled above the vents range between $4^{\circ} \mathrm{C}$ and $14^{\circ} \mathrm{C}$, with elements such as $\mathrm{Si}, \mathrm{Ba}$, and $\mathrm{He}$ varying linearly with temperature (Corliss et al., 1979a), a consequence of mixing of hydrothermal fluids and sea water. By use of the silica geothermometer of Fournier and Truesdell (1974), Corliss et al. (1979b) infer temperatures of $300^{\circ} \mathrm{C}$ for the original hydrothermal fluids.

At the East Pacific Rise crest at $21^{\circ} \mathrm{N}$, actual exit temperatures of fluids above vents are in excess of $350^{\circ} \mathrm{C}$ (Edmond et al., 1979a). Here, but not at the Galapagos Rift, syngenetic sulfides are precipitating directly from the hot hydrothermal fluids. These are deposited as mounds or chimney structures which consist of sphalerite, pyrite, chalcopyrite, amorphous silica, $\mathrm{Fe}$ oxides, and traces of orthorhombic sulfur (CYAMEX, 1979; Haymon et al., 1979; Hekinian et al., 1980). The venting solutions themselves carry suspended platelets of pyrrhotite (Macdougall et al., 1979). The sulfide deposits are concentrated in the hollow chimneys from which the hot fluids spout. Edmond et al. (1979c) explain the contrast between the $21^{\circ} \mathrm{N}$ and Galapagos Rift locales as follows. The iron hydroxide facies is within a spectrum of sediment types produced by mixing of hydrothermal fluids venting from the sea floor at temperatures in excess of $350^{\circ} \mathrm{C}$, and sea water. Sulfide deposits, iron hydroxides, and manganese oxides represent successive increments of mixing (i.e., dilution of the hydrothermal component), temperature reduction, and oxidation. Much of this apparently occurs within the crust at the Galapagos Rift. But at $21^{\circ} \mathrm{N}$ on the East Pacific Rise, hot, little-diluted hydrothermal fluids can reach the sea floor. We speculate that this is related to a greater rate of magma supply at the East Pacific Rise, coupled with development of a larger and shallower subaxial magma reservoir and conduit system, than at the Galapagos Rift (e.g., Natland, Axial Magma Chambers chapter, this volume). Corliss et al. (1979b) argue that a major portion of the cooling of oceanic crust must occur at rift axes, based on observations at the Galapagos Rift axial hydrothermal vents, theoretical considerations (Lister, 1977, 1978), and observations in ophiolites (e.g., Coleman, 1977; Dewey and Kidd,
1977). He also believes that hydrothermal cooling of rise and ridge regions acts to consolidate magmas in axial magma reservoirs such as are inferred from geophysical evidence beneath the East Pacific Rise (Rosendahl, 1976) and Galapagos Rift (Rosendahl et al., 1978). If this is so, then it seems reasonable that the thermal structure of any particular rise or ridge axis (i.e., the depth, size, continuity, and replenishment rate of the magma chamber) could dictate both the type and volume of axial hydrothermal exhalations reaching the sea floor. Although the number of studied (and discovered) metalliferous sediment localities is low, sea-floor sulfide deposits by this reasoning would be more abundant on the East Pacific Rise than the Galapagos Rift, and certainly the Mid-Atlantic Ridge. Moreover, the volume of hydrothermal exhalations must be greater on the East Pacific Rise, since the iron hydroxide facies is an important part of sediments at Site 420 , but is minor at Sites 424 and 425 on the Galapagos Rift.

A major question concerns how far the various chemical constituents of hydrothermal solutions vented into bottom waters at rise or ridge crests can disperse. Evidently, on the Galapagos Rift, Mn produced at axial fissures is detectable in the water column over 1000 meters above the sea floor and has a mean dispersal distance of about $1500 \mathrm{~km}$ (Weiss, 1977). Dispersal distances for Fe have not been calculated, but based on our Site 420 data, they must be at least several hundred kilometers on the East Pacific Rise. Based on Site 425, they would be less on the Galapagos Rift, although this conclusion is complicated by higher sedimentation rates and slower bottom currents in the Panama Basin than over the East Pacific Rise. Whether transport of iron over such distances occurs in the form of suspended particles, or in solution, or both, is also uncertain. At the Galapagos Rift, for manganese it is evidently both (Klinkhammer et al., 1977).

If sulfide deposits are typical on the crest of the East Pacific Rise, then the iron hydroxide facies encountered at Site 420 may result from oxidation of sulfide particles vented into bottom waters or oxidation of the vents themselves. The chimneys are reported to be crusted with gossan-type iron hydroxides and appear to alter progressively to iron hydroxides after venting ceases (e.g., CYAMEX, 1979). A similar phenomenon has been observed in and near sulfide deposits of the Troodos ophiolite on Cyprus (Robertson and Fleet, 1976). We do not believe that we cored similar sediments even in reworked or redeposited form, since transition trace metal abundances at Site 420 appear to be too low $(\mathrm{Cu}$ $=64-310 \mathrm{ppm}, \mathrm{Co}=44-339 \mathrm{ppm} ; \mathrm{Zn}=104-465 \mathrm{ppm}$, Mo $=44-73 \mathrm{ppm}$; data from Schrader et al., this volume). But this general pattern of oxidation of such materials, particularly those injected into suspension in bottom waters above the vents, could provide a source for the iron hydroxide facies which disperses in bottom waters for scores of kilometers away from the vents. Even from chimneys which consist mainly of zinc and copper sulfides, vented particulate matter consists of more than 90 per cent pyrrhotite (Macdougall et al., 1979). Therefore, considerable fractionation of $\mathrm{Cu}$ and 
$\mathrm{Zn}$ from Fe may occur within or near the vents, leaving a primarily ferruginous extract to disperse great distances from them.

Manganese is also being emitted from the sulfide vents at $21^{\circ} \mathrm{N}$ on the East Pacific Rise. Sharp spikes in "total dissolved Mn" as well as ${ }^{3} \mathrm{He} /{ }^{4} \mathrm{He}$ occur in the water column some 200 meters above the sea floor and the vents (Lupton et al., 1979). Mn is present in even higher abundances in waters sampled just above the vents; it therefore appears to be precipitating near the vents in some form. Much of it, however, must be fairly widely dispersed, based on Weiss's (1977) 1000 km dispersal distance from the Galapagos Rift. We therefore argue that both the $\mathrm{Fe}$ and the Mn enrichments within Leg 54 East Pacific Rise sediments could have stemmed from sulfide vents at the rise crest.

One potential source of axial hydrothermal sediments that has yet to be observed is volcanic activity itself. Sea water and formation-fluid fluxes undoubtedly will be greatly acclerated even by subterranean magma movements as the extreme heat of molten material approaches the sea floor. Eruptions will promote extremely violent and large-volume exchange between hydrothermal waters and sea water. Thermal plumes should rise to correspondingly greater heights in the water column, and dispersal distances will be greater. Components leached from heated rock as well as those in magmatic fluid phases will be mixed with bottom waters. Rateev et al. (this volume) describe fragments of volcanic glass in Leg 54 East Pacific Rise sediments that are partly transformed to clays, and partly encrusted with "earthy" iron hydroxides. Although most of the glass must have been incorporated into the sediments during slumping from surrounding outcrops and redistribution by currents, some of it could well have come from volcanic eruptions, whose great heat so agitated bottom waters that small glassey particles added to them were turbulently carried great distances from the rise crest. Since most igneous materials recovered or observed from the East Pacific Rise are basaltic flows or pillows, it is perhaps natural to suppose that eruptions there are typically fairly passive, as they are on Hawaii. But the degree of submarine phraetomagmatic activity could well be underestimated. For example, hollow, vertical, vesicular lava pillars above lava lakes on the Galapagos Rift have been interpreted as loci for passage of supercritical fluids through molten, ponded lava (Ballard et al., 1979). These may have resulted in something similar to subaerial lava fountaining. In any case, we see no reason to assume that such activity has only a negligible role in the production and dispersal of the rise-crest iron- and manganese-hydroxide facies. The evidence for it is incomplete, but dispersed volcanic glass, and dispersed high-temperature alkali feldspars in eastern Pacific sediments (Peterson and Goldberg, 1962; Bonatti and Arrhenius, 1970) may indicate that rather explosive volcanic activity is abundant on rise axes.

\section{The Iron-Nontronite Facies}

The iron-nontronite facies of the Galapagos Mounds is not among the sediment types linked by the model of
Edmond et al. (1979c). From its occurrence directly above source vents in the mounds field, we would like to propose this as a type locale for this type of deposit, just as the East Pacific Rise crest is the type locale for the iron hydroxide facies. Following Williams et al (1979), we believe that the most important aspect of the mounds locale is its position in fault-block terrain well south of the Galapagos Rift. In several papers which we have cited, Williams and co-workers identify the area as one with cellular-type hydrothermal circulation. The cells circulate entirely in hot, but nevertheless solid, rock to depths of perhaps $3-5 \mathrm{~km}$ in the crust (e.g., Williams et al., 1974; Wolery and Sleep, 1976).

The Galapagos mounds type locality for this facies is not unique. Two other occurrences that we have mentioned are the fracture zone "A" deposits (Hoffert et al., 1978) and the Gulf of Aden deposits (Cann et al., 1977). Like the mounds deposits, the fracture zone " $A$ ", deposits are definitely off-axis. The Gulf of Aden deposits are from a median rift setting, but this is a slowspreading ridge $(0.9-1.1 \mathrm{~cm} / \mathrm{y}$; Laughton et al., 1970) where axial magma reservoirs are probably small and intermittently developed (Nisbet and Fowler, 1978; Sleep and Rosendahl, 1979). Circulation of hydrothermal fluids to depths of several kilometers in the crust, and lower exit temperatures, are perfectly consistent with both situations.

Two additional probable occurrences of the ironnontronite facies were discussed in connection with methods for evaluating sediment chemistry. These are the Bauer Deep and DOMES Site C sediments, which both occur on fast-spreading crust generated at the East Pacific Rise. A case can be made that both are off-axis deposits, although this has been disputed for the Bauer Deep sediments (see below). Also, although these deposits have been extensively studied, no one has heretofore identified them with the iron-nontronite facies. Bischoff et al. (in press) have argued for a diagenetic origin of the DOMES Site C hydrothermal sediments (basically the iron hydroxide-biogenic opal reaction of Heath and Dymond, 1977). We have disagreed with this interpretation, because there should be a complete spectrum of clay compositions with variable, rather than fixed, ratios of excess $\mathrm{Fe}_{2} \mathrm{O}_{3}$ to excess $\mathrm{SiO}_{2}$, and $\mathrm{Fe}_{2} \mathrm{O}_{3} / \mathrm{Al}_{2} \mathrm{O}_{3}$. But these ratios at DOMES Site $\mathrm{C}$ are fixed, and identi$\mathrm{cal}$ to that of the mounds iron nontronites. Bischoff et al. (in press) realized that a very precise and persistent set of geochemical conditions would need to exist to produce clay compositions by diagenesis which are so uniform. We offer a much simpler alternative: that DOMES Site $\mathrm{C}$ sediments include an iron-nontronite (and manganese oxide) hydrothermal component virtually identical to that at the Galapagos Mounds.

On the basis of heat flow data, Anderson and Halunen (1974) favored a local (off-axis) origin for the Bauer Deep metalliferous sediments. Lonsdale (1976), however, argued that prevailing bottom currents wafted the sediments from the East Pacific Rise, some kilometers to the west, to the Bauer Deep. We feel, however, that if this were the case, the sediments would look like those at Site 420. Instead, the Bauer Deep sediments resemble 
the Galapagos Mounds deposits. Although we cannot explicitly disprove the dispersal argument for the Bauer Deep sediments, we consider it unlikely in view of what we believe to be the general occurrence of the iron-hydroxide facies at the crest of the East Pacific Rise, and the iron-nontronite facies in more restricted off-axis occurrences, none of which shows any evidence for dispersal nor has viable dispersal mechanisms. For example, the DOMES Site $\mathrm{C}$ deposits are local to the extent that hydrothermal sediments are not present at DOMES Sites A or B, which are nearby. Any transport mechanism would also have to involve $\mathrm{Si}$ and $\mathrm{Mg}$, neither of which is evident in iron hydroxide sediments sampled closer to the rise axis.

Experimental data and observations on sea-floor igneous rocks support our contention that the East Pacific Rise iron-hydroxide facies is a manifestation of hightemperature processes, whereas the Galapagos Mounds result from lower-temperature water/rock interactions. Mottl and Holland (1978) and Mottl et al. (1979) report that $\mathrm{SiO}_{2}, \mathrm{Fe}$, and $\mathrm{Mn}$ were all leached from basalts in experiments with sea water between $200^{\circ}$ and $500^{\circ} \mathrm{C}$, but the concentrations of $\mathrm{Fe}$ and $\mathrm{Mn}$ in the reacting solutions were low at $200^{\circ}-300^{\circ} \mathrm{C}$, and increased greatly with temperature between $300^{\circ}$ and $500^{\circ}$. They relate the low $\mathrm{Fe}$ and $\mathrm{Mn}$ at $200^{\circ}-300^{\circ}$ to uptake by smectites under slightly acid conditions. Reduced sulfur was leached from basalts into solution, and was also produced by reaction of ferrous iron and sea-water sulfate. This reaction was greatly accelerated at higher temperatures. These experiments thus predict markedly higher ratios of $\mathrm{Fe} / \mathrm{Si}$ in solutions with high-exit temperatures $\left(300^{\circ}-400^{\circ}\right.$, such as the East Pacific Rise crest at $\left.21^{\circ} \mathrm{N}\right)$, and moreover that most of the $\mathrm{Fe}$ will be reduced. This seems to match the rise-crest sulfide facies precisely. The iron-hydroxide facies, then, following Edmond et al. (1979c), can be produced simply by mixing of similar reduced high-temperature fluids with sea water on the sea floor. This acts to cool and oxidize them, and promotes precipitation of iron hydroxides.

In the case of off-axis hydrothermal cells, temperatures of $300^{\circ}-500^{\circ} \mathrm{C}$ will exist only hundreds or perhaps thousands of meters deep in the crust, where greenschist facies metamorphic rocks are produced (e.g.,Wolery and Sleep, 1976; Cann, 1979). In order for such deeply circulating solutions to reach the sea floor, they must partly or largely react with shallower, colder rocks, and probably be mixed to some extent with colder sea water drawing down into the crust. This is borne out by the data of Humphris and Thompson (1978a,b) on Mid-Atlantic Ridge basalts altered to greenschist facies. In general, $\mathrm{SiO}_{2}$ and $\mathrm{CaO}$ are leached from the basalts, and $\mathrm{MgO}$ and $\mathrm{H}_{2} \mathrm{O}$ are taken up. $\mathrm{Fe}, \mathrm{Mn}, \mathrm{Cu}$, and other trace metals are also mobilized, but appear to be taken up, in part, by secondary minerals located in veins and vesicles in the same rocks. We speculate that the solutions which produce this typical, deep crustal alteration are cooled and partly oxidized en route to the surface, and have sufficient dissolved silica to become nearly saturated with silicate phases. The experiments of Seyfried and Bischoff (1977) indicate that these could be either opal, at high rock/water ratios, or smectite, at lower ratios. If some of the iron is reduced, and the fluids are hot enough, pyrite will also form by reduction of seawater sulfate. Some evidence exists for this at Site 456, which is in a high heat-flow area in the Mariana Trough inter-arc basin in the western Pacific. There, clay minerals, opal, quartz, and pyrite have precipitated in veins and vesicles in chloritized basalts (Hussong, Uyeda, et al., 1978; Natland and R. Hekinian, unpublished data). Also, in basalts at our own Site 425 north of the Galapagos Rift, we found patches and vesicle fillings of a green clay mineral similar in appearance to the green iron nontronites of Site 424. X-ray diffraction and chemical analyses of a similar type of vein mineral in Core 9 of Hole 425 (Hekinian et al., 1978) show it to be nontronitic, with high $\mathrm{Fe}_{2} \mathrm{O}_{3}(\sim 39 \%), \mathrm{SiO}_{2}$ of about 37 per cent, and less than 1 per cent $\mathrm{Al}_{2} \mathrm{O}_{3}$. Intimately associated with the smectite in the veins (Figure 18) is a dark, reddish-brown amorphous iron hydroxide with 55-70 per cent $\mathrm{Fe}_{2} \mathrm{O}_{3}, 6-12$ per cent $\mathrm{SiO}_{2}$, and 1-3 per cent $\mathrm{MgO}$. Evidently it has a small clay-mineral component. Sulfides fill voids and veins at various depths in these basalts (Schrader et al., this volume). The entire paragenesis is consistent with successive or alternating passage of oxidized and reduced hydrothermal fluids through the basalts, leaving clay minerals, iron hydroxides, and sulfides in their wake.

\section{SUMMARY}

In this chapter we have outlined the occurrence of two types of sedimentary hydrothermal deposits, exemplified by the sediments we cored. Site 420 on the East Pacific Rise contains a diagenetically transformed ironrich facies, originally iron hydroxides, supplied to the site through the water column by emanations from the East Pacific Rise. The deposits are probably related to fluids which also produce the rise-axis sulfide facies, such as found at $21^{\circ} \mathrm{N}$. The iron hydroxides form after these fluids are diluted, oxidized, and reduced in temperature, all incurred by mixing with sea water. Iron hydroxides could also form by oxidation of sulfide deposits by exposure to sea water after precipitation.

At Site 424 on the south flank of the Galapagos Rift, we cored manganese oxides and abundant, very pure, and compositionally uniform iron nontronites capping and interbedded with pelagic sediments. These form distinct mounds and contain considerably heated pore fluids. Following Williams et al. (1979), we relate these to development of an off-axis hydrothermal circulation system, acting entirely in hot, but solid rock.

The graphical and computational techniques which we have used to distinguish the iron-hydroxide and ironnontronite facies have proved useful in identifying two other probable iron-nontronite occurrences in the eastern Pacific - in the Bauer Deep and at DOMES Site C. Clay minerals at these locations were previously thought to form by diagenetic reaction between iron hydroxides and biogenic opaline silica. This we now discount because such reactions have occurred at Site 420 , but have resulted in different chemical relationships and clay compositions than at either DOMES Site $\mathrm{C}$ or the Bauer Deep. 


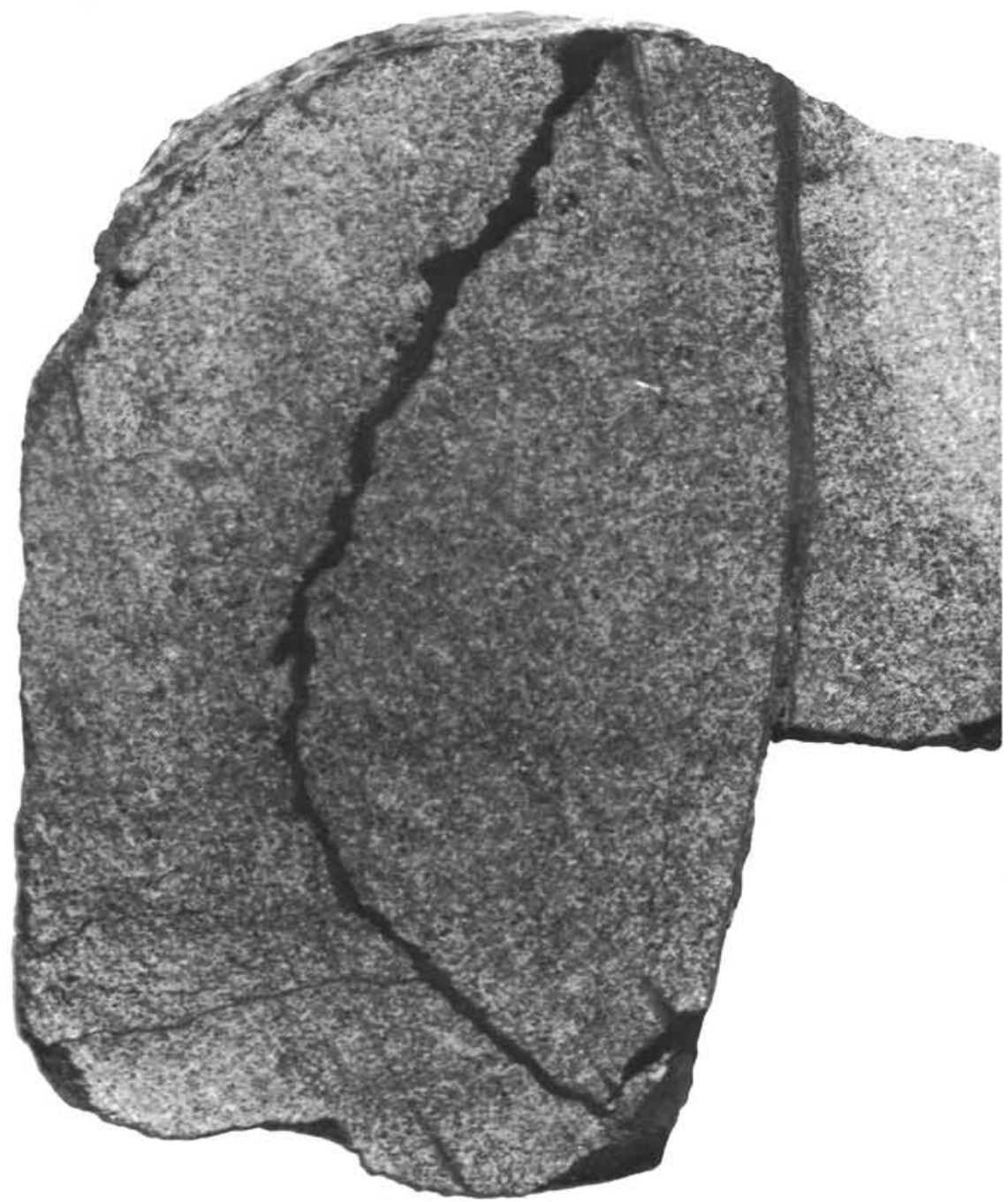

Figure 18. Sawed surface of veined basalt, Section 425-9-1 (Piece 10). Vein to right is lined with green clays and cored with $\mathrm{Fe}-\mathrm{Mn}$ hydroxides. Darker material in vein to right is mainly $\mathrm{Fe}-\mathrm{Mn}$ hydroxides. Sample is about $5.5 \mathrm{~cm}$ long.

Experimental data, and consideration of the geochemical consequences of the alteration of oceanic igneous rocks to greenschist facies, provide a useful framework within which to view the origin of the two types of sediments. Of considerable importance are the higher ratio of $\mathrm{Fe} / \mathrm{Si}$ in solutions produced experimentally by reacting sea water with basalt at high temperatures $\left(300-500^{\circ} \mathrm{C}\right)$, plus the generally reduced state of those solutions. We argue that in some high-temperature riseaxis regimes (e.g., the East Pacific Rise), similar solutions vent directly onto the sea floor because of proximity to axial magmas. But in off-axis settings, even if hydrothermal solutions reach such elevated temperatures, it can only be at depths of several kilometers, and the solutions are modified before reaching the surface by subsequent reactions with igneous rocks, by cooling, and, in many cases, by oxidation. This acts to reduce $\mathrm{Fe} / \mathrm{Si}$. Iron nontronites precipitate if the solutions are sufficiently oxidized in the crust, or upon expulsion onto the sea floor. Manganese is fractionated from iron, and iron from $\mathrm{Cu}$ and $\mathrm{Zn}$, by gradients in oxygenation and temperature. $\mathrm{Cu}$ and $\mathrm{Zn}$ concentrate principally in sulfide minerals in the crust or at axial vents, depending on the conditions affecting exiting hydrothermal fluids. Except in trace quantities, they are never dispersed far from axial vents. Iron precipitates at high temperatures as sulfides in the crust or at axial vents, and can be dispersed as iron hydroxides far from such vents. Manganese is almost entirely dispersed into bottom water away from high-temperature axial vents. Even at low-temperature vents such as the Galapagos Mounds, Mn oxides form further from sources than any other precipitate.

\section{ACKNOWLEDGMENTS}

This paper would not have been possible without contributions to this volume by several groups of workers. We are especially indebted to Nick Donnelly, whose data constitute much of the quantitative basis of this paper. We appreciate and gratefully acknowledge discussions with our shipboard colleagues, and with Jim Bischoff, Joe Cann, Dave Cronan, Jack 
Dymond, Joris Gieskes, and Peter Lonsdale, all of whom contributed significantly to the ideas presented here. We also thank our reviewers, Peter Borella and Chuck Adelseck.

\section{REFERENCES}

Anderson, R. N., and Halunen, J., 1974. Implications of heat flow for metallogenesis in the Bauer Deep, Nature, v. 251, p. $473-475$.

Arrhenius, G., 1963. Pelagic sediments. In Hill, M. N. (Ed.), The Sea (Vol.3): New York (Wiley), p. 655-727.

Ballard, R. D., Holcomb, R. T., and van Andel, Tj. H., 1979. The Galapagos Rift at $86^{\circ} \mathrm{W}, 3$, sheet flows, collapse pits, and lava lakes of the rift valley, J. Geophys. Res., v. 84, p. 5407-5422.

Berger, W. H., 1967. Foraminiferal ooze: solution at depths, Science, v. 156, p. 383-385.

1973. Deep-sea carbonates: Pleistocene dissolution cycles, J. Foram. Res., v. 3, p. 187-195.

Berger, W. H., and Mayer, L. A., 1978. Deep-sea carbonates: acoustic reflectors and lysocline fluctuations, Geology, v. 6, p. 11-15.

Bischoff, J. L., 1969. Red Sea geothermal brine deposits: their mineralogy, chemistry and genesis. In Degens, E. T., and Ross, D. A. (Eds.), Hot Brines and Recent Heavy Metal Deposits in the Red Sea: Berlin, Heidelberg, New York (Springer), p. 368-401.

Bischoff, J. L., Heath, G. R., and Leinen, M., 1979a. Geochemistry of deep-sea sediments from the Pacific manganese nodule province: DOMES Sites A, B, and C. In Bischoff, J. L., and Piper, D. Z. (Eds.), Marine Geology and Oceanography of the Pacific Manganese Nodule Province: New York (Plenum), p. 397-436.

Bischoff, J. L., Piper, D. Z., and Quintero, P., 1979b. Nature and origin of metalliferous sediment in DOMES Site $\mathrm{C}$, Pacific manganese nodule province. In Colloques Internationaux du Centre National de la Recherche Scientifique No. 289 - La Génèse des Nodules de Managanese,p. 119-137.

Bischoff, J. L., and Rosenbauer, R. J., 1977. Recent metalliferous sediment in the North Pacific manganese nodule area, Earth Planet. Sci. Lett., v. 33, p. 379-388.

Bonatti, E., and Arrhenius, G., 1970. Acidic rocks on the Pacific Ocean floor. In Maxwell, A. E. (Ed.), The Sea (Vol. 4): New York (Wiley), p. 445-464.

Bonatti, E., and Joensuu, O., 1966. Deep-sea iron deposits from the South Pacific, Science, v. 154, p. 643-645.

Boström, K., and Peterson, M. N. A., 1966. Precipitates from hydrothermal exhalations on the East Pacific Rise, Econ. Geol., v. 61, p. 1258-1265.

Boström, K., Peterson, M. N. A., Joensuu, O., and Fisher, D. E., 1969. Aluminum-poor ferromanganoan sediments on active ocean ridges, J. Geophys. Res., v. 74, p. 3261-3270.

Broecker, W. S., 1971. Calcite accumulation rates and glacial to interglacial changes in oceanic mixing. In Turekian, $\mathrm{K}$. K. (Ed.), The Late Cenozoic Glacial Ages: New Haven (Yale University Press), p. 239-265.

Cann, J. R., 1979. Metamorphism in the ocean crust. In Talwani, M. Harrison, C. G, and Hayes, D. E. (Eds.), Deep Drilling Results in the Atlantic Ocean: Ocean Crust, Maurice Ewing Series 2: Washington (American Geophysical Union), p. 230-238.

Cann, J. R., Winter, C. K., and Pritchard, R. G., 1977. A hydrothermal deposit from the floor of the Gulf of Aden, Miner. Mag., v. 41, p. 193-199.

Coleman, R. G., 1977. Ophiolites: Berlin, Heidelberg, New York (Springer).

Cook, H. E., 1972. Stratigraphy and sedimentation. In Hays, J. D., et al., Initial Reports of the Deep Sea Drilling Pro- ject, 9: Washington (U.S. Govt. Printing Office), p. 933-944.

Corliss, J. B., Dymond, J. R., Gordon, L. I., Edmond, J. M., Von Herzen, R. P., Ballard, R. D., Green, K., Williams, D. L., Bainbridge, A., Crane, K., and van Andel, Tj. H., 1979a. Submarine thermal springs on the Galapagos Rift, Science, v. 203, p. 1073-1083.

Corliss, J., Gordon, L. I., and Edmond, J. M., 1979b. Some implications of heat/mass ratios in Galapagos Rift hydrothermal fluids for models of sea-water-rock interaction and the formation of oceanic crust. In Talwani, M., Harrison, C. G., and Hayes, D. E. (Eds.), Deep Drilling Results in the Atlantic Ocean: Ocean Crust, Maurice Ewing Series 2: Washington (American Geophysical Union), p. 391-402.

Corliss, J. B., Lule, M., Dymond, J. R., and Crane, K., 1978. The chemistry of hydrothermal sediment mound deposits near the Galapagos Rift, Earth Planet. Sci. Lett. v. 40, p. 12-24.

Crane, K., 1978. Structure and tectonics of the Galapagos inner rift, $86^{\circ} 10^{\prime} \mathrm{W}, J$. Geol., v. 86, p. 715-730.

Cronan, D. S., 1969. Average abundances of Mn, Fe, Ni, Co, $\mathrm{Cu}, \mathrm{Pb}, \mathrm{Mo}, \mathrm{V}, \mathrm{Cr}, \mathrm{Ti}$, and $\mathrm{P}$ in Pacific pelagic clays, Geochim. Cosmochim. Acta, v. 33, p. 1562-1565.

1972. Regional geochemistry of ferromanganese nodules in the world ocean. In Horn, D. R. (Ed.), Ferromanganese Deposits on the Ocean Floor: Palisades, N.Y. (Lamont-Doherty Geological Observatory), p. 19-30.

Cronan, D. S., and Tooms, J. S., 1969. The geochemistry of manganese nodules and associated pelagic deposits from the Pacific and Indian oceans, Deep-Sea Res., v. 16, p. 335-339.

CYAMEX Science Team, 1979. Massive deep-sea sulfide ore deposits recovered on the East Pacific Rise, Nature, v. 277, p. 523-528.

Detrick, R. S., Williams, D. L., Mudie, J. D., and Sclater, J. G., 1974. The Galapagos spreading centre: bottom-water temperatures and the significance of geothermal heating, Geophys. J. Roy. Astron. Soc., v. 38, p. 627-637.

Dewey, J. F., and Kidd, W. S. F., 1977. Geometry of plate accretion, Geol. Soc. Am. Bull., v. 88, p. 960-963.

Dunn, D. A., and Moore, T. C., Jr., in press. Late Miocene (Magnetic Epoch 5-Epoch 9) calcium carbonate stratigraphy of the equatorial Pacific Ocean, Mar. Geol.

Dymond, J., Corliss, J. B., Heath, G. R., Field, C. W., Dasch, E. J., and Veeh, H. H., 1973. Origin of metalliferous sediments from the Pacific Ocean, Geol. Soc. Am. Bull., v. 84 , p. $3355-3372$.

Edmond, J. M., Corliss, J. B., and Gordon, L. I., 1979a. Ridge crest hydrothermal metamorphism at the Galapagos spreading center and reverse weathering. In Talwani, M., Harrison, C. G., and Hayes, D. E. (Eds), Deep Drilling Results in the Atlantic Ocean: Ocean Crust, Maurice Ewing Series 2: Washington (American Geophysical Union), p. 383390.

Edmond, J. M., Craig, H., Gordon, L. I., and Holland, H. D., 1979b. Chemistry of hydrothermal waters at $21^{\circ} \mathrm{N}$ on the East Pacific Rise, EOS, v. 60, p. 864.

Edmond, J. M., Measures, C., Mangum, B., Grant, B., Sclater, F. R., Collier, R., Hudson, A., Gordon, L. I., and Corliss, J. B., 1979c. On the formation of metal-rich deposits at ridge crests, Earth Planet. Sci. Lett., v. 46, p. 19-30.

Fournier, R. O., and Truesdell, A. H., 1973. An empirical $\mathrm{Na}-\mathrm{K}-\mathrm{Ca}$ geothermometer for natural waters, Geochim. Cosmochim. Acta, v. 37, p. 1255-1275.

Griffin, J. J., and Goldberg, E. D., 1963. Clay-mineral distributions in the Pacific Ocean. In Hill, M. N. (Ed.), The Sea (Vol. 3): New York (Wiley), p. 728-741. 
Haymon, R., Macdougall, D., Kastner, M., Kerridge, J., and the Rise Scientific Team, 1979. Mineralogy and chemistry of hydrothermal sulfide deposits and sediments at EPR $21^{\circ}$ N. EOS, v. 60 , p. 864.

Hays, J. D., et al., 1972. Initial Reports of the Deep Sea Drilling Project, 9: Washington (U.S. Govt. Printing Office).

Heath, G. R., and Dymond, J., 1977. Genesis and transformation of metalliferous sediments from the East Pacific Rise, Bauer Deep, and Central Basin, northwest Nazca Plate, Geol. Soc. Am. Bull., v. 88, p. 723-733.

Hekinian, R., Fevrier, M., Bischoff, J. L., Picot, P., and Shanks, W. C.,1980. Sulfide deposits from the East Pacific Rise near $21^{\circ} \mathrm{N}$, Science, v. 207, p. 1433-1444.

Hekinian, R., Moore, J. G., and Bryan, W. G., 1976. Volcanic rocks and processes of the Mid-Atlantic Ridge rift valley near $36^{\circ} 49^{\prime}$, Contrib. Mineral. Petrol., v. 58, p. 83-110.

Hekinian, R., Rosendahl., B. R., Cronan, D. S., Dmitriev, Y., Fodor, R. V., Goll, R. M., Hoffert, M., Humphris, S. E., Mattey, D. P., Natland, J., Peterson, N., Roggenthen, W., Schrader, E. L., Srivastava, R. K., and Warren, N., 1978. Hydrothermal deposits and associated basement rocks from the Galapagos spreading center, Oceanol. Acta, v. 1, p. 473-482.

Hoffert, M., Perseil, A., Hekinian, R., Choukroune, P., Needham, H. D., Francheteau, J., and LePichon, X., 1978. Hydrothermal deposits sampled by diving saucer in transform fault " $\mathrm{A}$ " near $37^{\circ} \mathrm{N}$ on the Mid-Atlantic Ridge. Ibid., v. 1, p. 73-86.

Honnorez, J., Von Herzen, R. P., et al., in press. Galapagos hydrothermal mounds: results of Deep Sea Drilling Project Leg 70, Geol. Soc. Am. Bull.

Humphris, S. E., and Thompson, G., 1978a. Hydrothermal alteration of oceanic basalts by seawater, Geochim. Cosmochim. Acta., v. 42, p. 107-125.

$1978 \mathrm{~b}$. Trace element mobility during hydrothermal alteration of oceanic basalts, Ibid., v. 42, p. 127-136.

Hussong, D. M., Uyeda, S., and the Leg 60 Scientific Party, 1978.Leg 60 ends in Guam, Geotimes, v. 23 (10), p. 19-22.

Jenkins, W. J., Edmond, J. M., and Corliss, J. B., 1978. Excess ${ }^{3} \mathrm{He}$ and ${ }^{4} \mathrm{He}$ in Galapagos submarine hydrothermal waters, Nature, v. 272, p. 156-158.

Klinkhammer, G., Bender, M., and Weiss, R. F., 1977. Hydrothermal manganese in the Galapagos Rift, Ibid., v. 269 , p. $319-320$.

Klitgord, K. D., 1974. Near-bottom geophysical surveys and their implications on the crustal generation process, seafloor spreading history of the Pacific, and the geomagnetic time scale: 0 to 6 m.y.b.p. [Unpublished Ph.D. thesis]. University of California, San Diego.

Klitgord, K. D., and Mudie, J. D., 1974. The Galapagos spreading centre: a near-bottom geophysical survey, Geophys. J. Roy. Astron. Soc., v. 38, p. 563-586.

Krauskopf, K. B., 1957. Separation of manganese from iron in sedimentary processes, Geochim. Cosmochim. Acta, v. 12 , p. $61-84$.

Laughton, A. S., Whitmarsh, R. B., and Jones, M. T., 1970. The evolution of the Gulf of Aden, Roy. Soc. London Phil. Trans. A, v. 267, p. 227-266.

Lilly, M. D., and Gordon, L. I., 1979. Methane, nitrous oxide, carbon monoxide and hydrogen in the hydrothermal vents of the Galapagos spreading center, EOS, v. 60 , p. 863.

Lister, C. R. B., 1972. On the thermal balance of a Mid-Ocean Ridge. Geophys. J. Roy. Astron. Soc., v. 26, p. 515-535.
1974. On the penetration of water into hot rock, Ibid., v. 39, p. 465-509.

1977. Qualitative models of spreading center processes, including hydrothermal penetration, Tectonophysics, v. 37, p. 203-218.

1978. "Active" and "passive" hydrothermal systems in the oceanic crust: predicted physical conditions. In Benthic Boundary Layer Volume, Joint Oceanographic Assembly, Edinburgh, Scotland (1976), in press.

Lonsdale, P., 1976. Abyssal circulation of the southeastern Pacific and some geological implications, J. Geophys. Res., v. 81, p. $1163-1176$.

1977a. Deep-tow observations at the mounds abyssal hydrothermal field, Galapagos Rift, Earth Planet. Sci. Lett., v. 36, p. 92-110.

1977b. Abyssal pahoehoe with lava coils at the Galapagos rift, Geology, v. 5, p. 147-152.

Lonsdale, P., Burns, V., and Fisk, M., in press. Nodules of hydrothermal birnessite in the caldera of a young seamount, J. Geol.

Lonsdale, P., and Klitgord, K. D., 1978. Structure and tectonic history of the eastern Panama Basin, Geol. Soc. Am. Bull., v. 87, p. 157-173.

Lupton, J. E., Craig, H., and Klinkhammer, G., 1979. Helium- 3 and manganese at the $21^{\circ} \mathrm{N}$ EPR hydrothermal site, $E O S$, v. 60 , p. 864 .

Lupton, J. E., Weiss, R. F., and Craig, H., 1977. Mantle helium in hydrothermal plumes in the Galapagos Rift, Nature, v. 266, p. 603-604.

Macdougall, J. D., Finkel, B., and Chung, Y., 1979. Sulfide precipitates at $21^{\circ} \mathrm{N}$, EPR: uranium series isotopes, EOS, v. 60 , p. 864 .

McDuff, R. E., and Edmond, J. M., 1979. Sulfate and chloride in Galapagos Rift hydrothermal vent waters, Ibid., v. 60 , p. 864 .

Moore, W. S., and Vogt, P. R., 1976. Hydrothermal manganese crusts from two sites near the Galapagos spreading axis, Earth Planet. Sci. Lett., v. 29, p. 349-356.

Mottl, M. J., and Holland, H. D., 1978. Chemical exchange during hydrothermal alteration of basalt by seawater-I. Experimental results for major and minor components of seawater, Geochim. Cosmochim. Acta, v. 42, p. 11031115.

Mottl, M. J., Holland, H. D., and Corr, R. F., 1979. Chemical exchange during hydrothermal alteration of basalt by seawater-II. Experimental results for $\mathrm{Fe}, \mathrm{Mn}$, and sulfur species, Ibid., v. 43, p. 869-884.

Natland, J., Rosendahl, B., Hekinian, R., Dmitriev, Y., Fodor, R., Goll, R., Hoffert, M., Humphris, S., Mattey, D., Petersen, N., Roggenthen, W., Schrader, E., Srivastava, R., and Warren, N., 1979. Galapagos hydrothermal mounds: stratigraphy and chemistry revealed by Deep-Sea Drilling, Science, v. 204, p. 613-616.

Nisbet, E. G., and Fowler, C. M. R., 1978. The Mid-Atlantic Ridge at $37^{\circ}$ and $45^{\circ} \mathrm{N}$ : some geophysical and petrological constraints, Geophys. J. Roy. Astron. Soc., v. 54, p. 631660.

Peterson, M. N. A., and Goldberg, E. D., 1962. Feldspar distributions in South Pacific pelagic sediments, J. Geophys. Res., v. 67, p. 3477-3492.

Pisias, N. G., 1976. Late Quaternary sediment of the Panama Basin: sedimentation rates, periodicities, and controls of carbonate and opal accumulation, Geol. Soc. Am. Mem., v. 145 , p. $375-391$. 
Robertson, A. H. F., and Fleet, A. J., 1976. The origins of rare earths in metalliferous sediments of the Troodos Massif, Cyprus, Earth Planet. Sci. Lett., v. 28, p. 385-394.

Rosendahl, B. R., 1976. Evolution of oceanic crust 2: constraints, implications and inferences, J. Geophys. Res., v. 81, p. $5305-5314$.

Rosendahl, B. R., Russell, S. D., Dorman, L. M., and Johnson, S., 1978. Seismic model of the Galapagos Rift and comparison to EPR at $9^{\circ} \mathrm{N}, E O S$, v. 59, p. 1139.

Sayles, F. L., and Bischoff, J. L., 1973. Ferromanganoan sediments in the Equatorial East Pacific, Earth Planet. Sci. Lett., v. 19, p. 330-336.

Sclater, J. G., Anderson, R. N., and Bell, M. L., 1971. Elevation of ridges and evolution of the central Eastern Pacific, J. Geophys. Res., v. 76, p. 7888-7913.

Sclater, J. G., and Klitgord, K. D., 1973. A detailed heat flow, topographic, and magnetic survey across the Galapagos spreading center at $86^{\circ} \mathrm{W}$, Ibid., v. 78, p. 6951-6975.

Sclater, J. G., Von Herzen, R. P., Williams, D. L., Anderson, R. N., and Klitgord, K. D., 1974. The Galapagos spreading centre: heat-flow on the north flanks, Geophys. J. Roy. Astron. Soc., v. 38, p. 609-626.

Scott, M. R., Salter, P. F., and Barnard, L. A., 1979. Chemistry of ridge-crest sediments from the North Atlantic Ocean. In Talwani, M., Harrison, C. G., and Hayes, D. E. (Eds.), Deep Drilling Results in the Atlantic Ocean: Ocean Crust, Maurice Ewing Series 2: Washington (American Geophysical Union), p. 403-428.

Scott, M. R., Scott, R. B., Rona, P. A., Butler, L. W., and Nalwalk, A. J., 1974. Rapidly accumulating manganese deposit from the median valley of the Mid-Atlantic Ridge, Geophys. Res. Lett., v. 1, p. 355-358.

Scott, R. B., Rona, P. A., Butler, L. W., Nalwalk, A. J., and Scott, M. R., 1972. Manganese crusts of the Atlantis fracture zone, Nat. Phys. Sci., v. 239, p. 77-79.

Seyfried, W., and Bischoff, J. L., 1977. Hydrothermal transport of heavy metals by seawater: the role of seawater/ basalt ratio, Earth Planet. Sci. Lett., v. 34, p. 71-77.
Sleep, N. H., and Rosendahl, B. R., 1979. Topography and tectonics of Mid-ocean ridge axes, J. Geophys. Res., v. 84, p. 6831-6839.

Temple, D. G., Scott, R. B., and Rona, P. A., 1979. Geology of a submarine hydrothermal field, Mid-Atlantic Ridge, $26^{\circ} \mathrm{N}$ Latitude, Ibid., v. 84, p. 7453-7466.

Timofeev, P. P., Varentsov, I. M., Rateev, M. A., and Renngarten, N. V., 1978. Lithology, mineralogy, and geochemistry of upper Cenozoic sediments at $23^{\circ} \mathrm{N}$ near the Mid-Atlantic Ridge drilled on Leg 45. In Melson, W. G., Rabinowitz, P. D., et al. Initial Reports of the Deep Sea Drilling Project, 45: Washington (U.S. Govt. Printing Office), p. 323-348.

Tracey, J. I., Jr., Sutton, G. H., et al., 1971. Initial Reports of the Deep Sea Drilling Project, 8: Washington (U.S. Govt. Printing Office).

Turekian, K. K., and Wedepohl, K. H., 1961. Distribution of elements in some major units of the Earth's crust, Geol. Soc. Am. Bull., v. 71, p. 175-192.

Weiss, R. F., 1977. Hydrothermal manganese in the deep sea: scavenging, residence time, and $\mathrm{Mn} /{ }^{3} \mathrm{He}$ relationships, Earth Planet. Sci. Lett., v. 37, p. 257-262.

Weiss, R. F., Lonsdale, P. F., Lupton, J. E., Bainbridge, A. E., and Craig, H., 1977. Hydrothermal plumes at the Galapagos Rift, Nature, v. 267, p. 600-603.

Welhan, J. A., and Craig, H., 1979. Methane and hydrogen in East Pacific Rise hydrothermal fluids. EOS, v. 60, p. 863.

Williams, D. L., Green, K., van Andel, Tj. H., Von Herzen, R. P., Dymond, J., and Crane, K., 1979. The hydrothermal mounds of the Galapagos Rift: observations with DSRV Alvin and detailed heat flow studies, J. Geophys. Res., v. 84, p. 7467-7484.

Williams, D. L., Von Herzen, R. P., Sclater, J. G., and Anderson, R. N., 1974. The Galapagos spreading centre, lithospheric cooling and hydrothermal circulation, Geophys. J. Roy. Astron. Soc., v. 38, p. 587-608.

Wolery, T. J., and Sleep, N. H., 1976. Hydrothermal circulation and geochemical flux at mid-ocean ridges, J. Geol., v. 84 , p. $249-275$. 